\title{
Drug Patent Settlements Between Rivals: A Survey
}

\author{
C. Scott Hemphill \\ Columbia Law School
}

Working paper available at ssrn.com/abstract=969492

March 12, 2007 


\section{Drug Patent Settlements Between Rivals: A Survey \\ C. Scott Hemphill*}

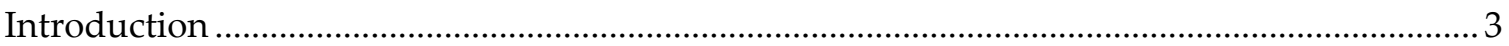

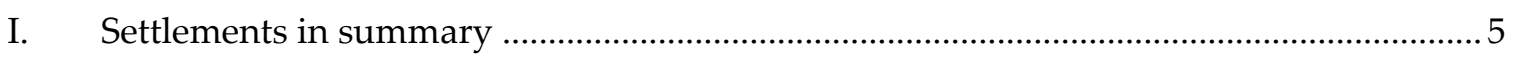

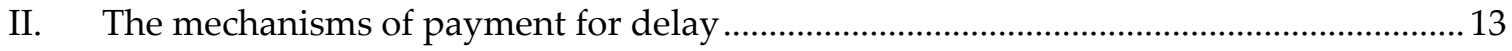

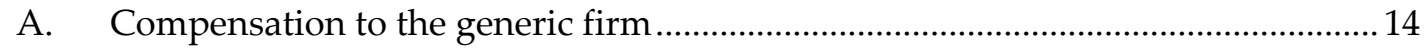

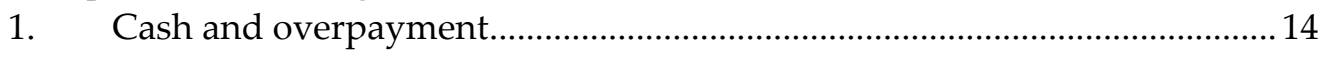

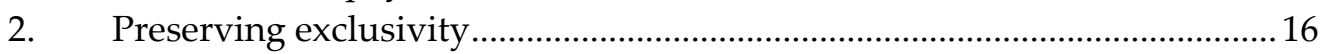

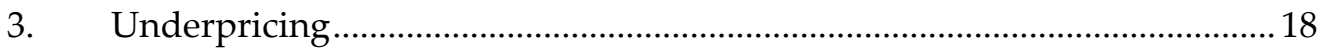

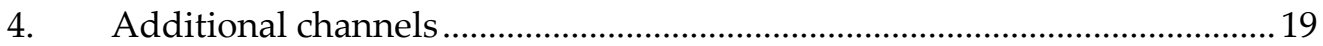

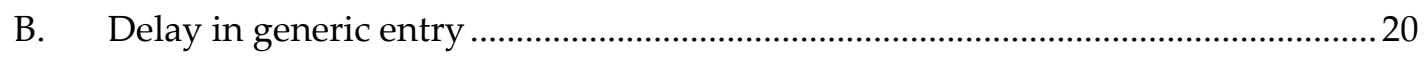

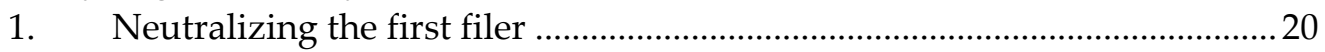

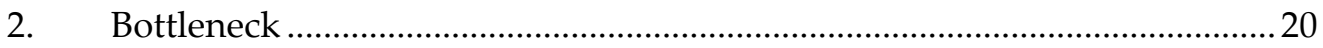

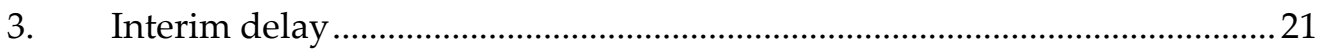

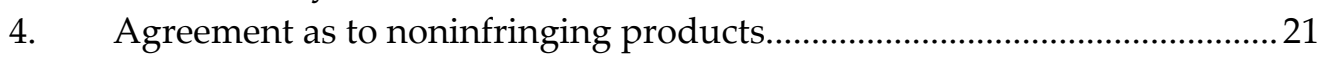

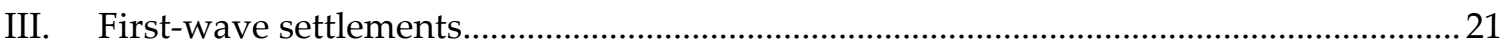

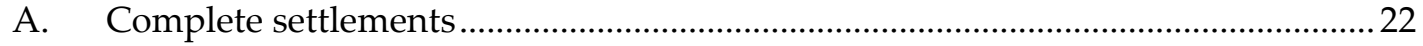

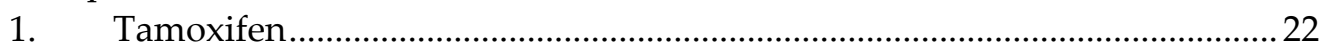

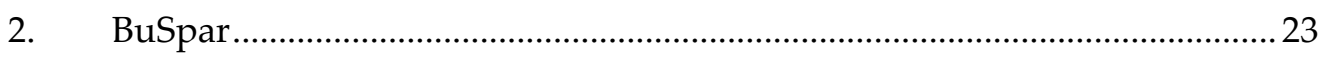

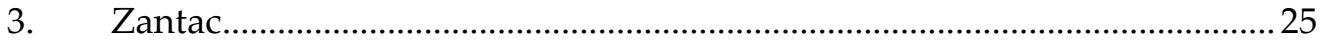

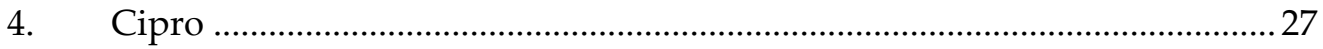

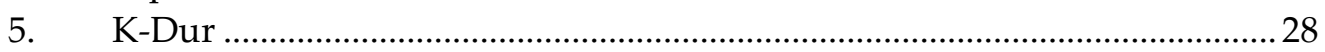

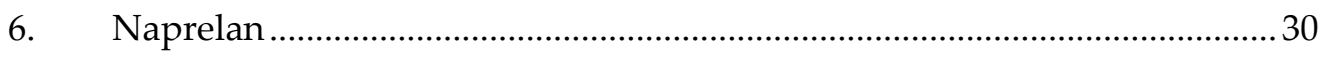

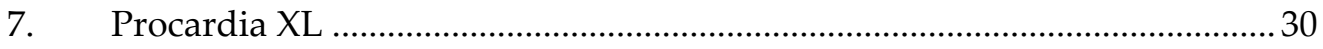

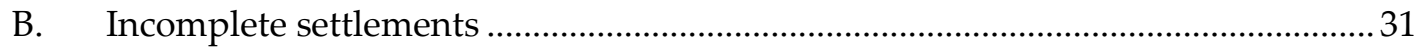

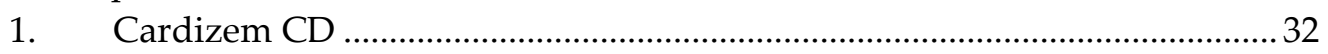

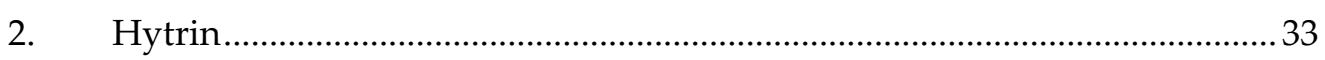

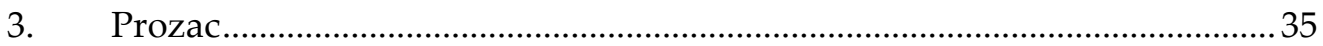

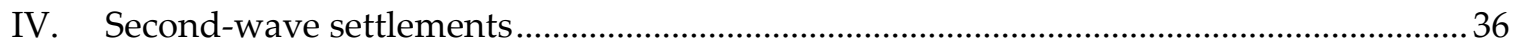

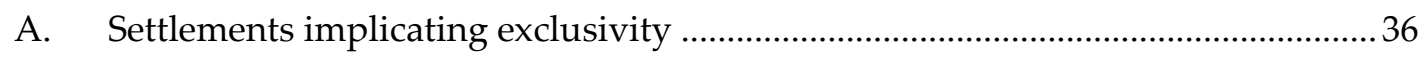

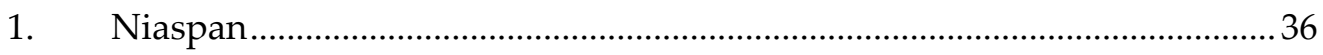

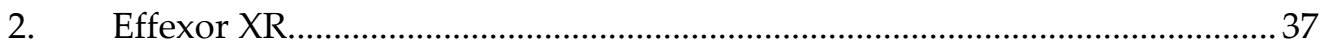

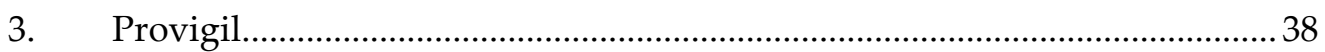

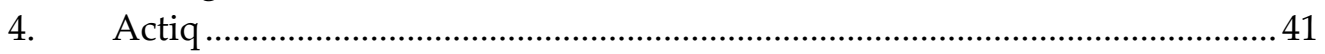

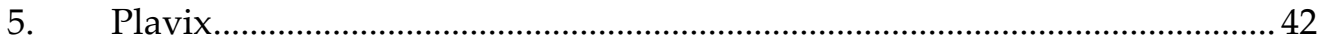

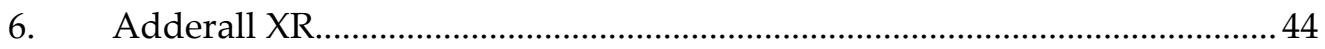

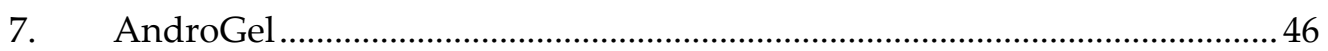

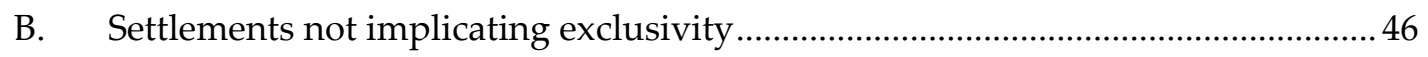

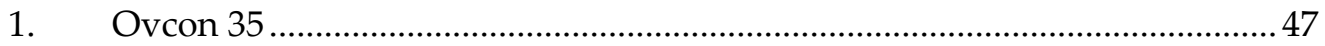

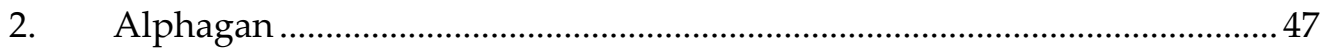

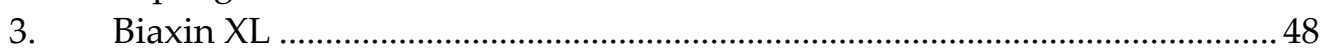




\section{Introduction}

This survey classifies and analyzes patent settlements reached between innovator drug makers and their generic rivals over the past fourteen years, and the antitrust suits and investigations initiated in response. Thirty settlements involving twenty drugs fall within its scope. Several patterns emerge from the data.

Continued expansion in antitrust activity. Settlements involving ten drugs have attracted antitrust suits or Federal Trade Commission investigations that are currently pending - sixteen suits and three investigations in all, not counting multiple suits consolidated in a single jurisdiction. The first settlement, a 1993 agreement to delay entry and settle a patent dispute involving the cancer drug tamoxifen, attracted a challenge that is pending as a petition for certiorari at the Supreme Court. ${ }^{1}$

Not all settlements have antitrust challenges pending. Antitrust challenges to a few settlements have been resolved, and a few settlements never attracted an antitrust challenge. For example, the maker of Zantac, the first blockbuster drug, apparently paid \$133 million to a generic rival, plus other consideration, to resolve a patent dispute. The Zantac settlement never invited antitrust attention, perhaps because the terms were not made public.

Emergence of repeat players. Of the seventeen innovators and eighteen generic firms that are party to the settlements, a few appear repeatedly. Generic firm Barr Laboratories, for example, reached settlements with respect to eight different drugs. Barr's first three settlements - tamoxifen, Cipro, and Ovcon 35yielded antitrust suits that are pending as, respectively, a petition for certiorari, a Second Circuit appeal, and a district court suit. Its last three settlementsAdderall XR, Provigil, and Actiq - are the subjects of FTC investigations. ${ }^{2}$

Increased sophistication in second-wave settlements. The settlements have occurred in two distinct waves. The first wave occurred between 1993 and 2000.

\footnotetext{
* Associate Professor, Columbia Law School. Akshay Deoras and Doug Geyser provided outstanding research assistance. This is a work in progress. Comments and corrections are welcome; please send them to hemphill@law.columbia.edu.

${ }^{1}$ This survey refers to each drug by its brand name, with the exception of Nolvadex, better known by its trade name tamoxifen.

2 See Barr Pharmaceuticals, Inc., Quarterly Report (Form 10-Q), at 15-17 (Nov. 9, 2006) (link), which discusses the suits and investigations, with the exception of the Actiq investigation, which has been disclosed by Cephalon. See Part IV.A.4 infra.
} 
FTC antitrust enforcement activity then halted settlements for a few years. But rulings adverse to antitrust liability by two federal appeals courts in 2005 and $2006^{3}$ have led to a new wave of settlements.

The two waves share a basic structure: the innovator confers value upon the generic firm, and the generic firm agrees to delay entry. Second-wave settlements differ from first-wave settlements, however, in their sophistication. For example, second-wave agreements provide for generic entry prior to, rather than only after, patent expiration. Moreover, in many second-wave settlements the generic firm provides value to the innovator that is distinct from delayed entry. The additional value takes several forms, including intellectual property, product development, manufacturing, supply, inventory, and promotion. This contribution of additional consideration complicates antitrust evaluation. In addition, second-wave settlements lack restrictions on entry with respect to noninfringing products, one of the bases used to challenge first-wave settlements.

This survey is the first to offer a comprehensive account of the agreements and subsequent antitrust activity. It builds upon FTC reports in 2002, 2006 and $2007^{4}$ that, unlike the present study, do not discuss individual agreements in detail or by name. For several settlements, this survey describes important settlement terms that can be inferred from FTC reports - for example, the size of the cash payment in the Zantac settlement.

The scope of the study is limited in several respects. First, it understates settlement activity due to its reliance on public information. Some settlements are clearly missing, judging from the settlement counts reported by the FTC. Second, some settlements have been omitted. For a drug to be included, an innovator must have entered into an agreement with a generic firm that was first to file an Abbreviated New Drug Application ("ANDA"). All but one ${ }^{5}$ of the drugs in the study are protected by one or more patents, and the filed ANDA

${ }^{3}$ See Schering-Plough Corp. v. FTC, 402 F.3d 1056 (11th Cir. 2005); In re Tamoxifen Citrate Antitrust Litig., 466 F.3d 187 (2d Cir. 2006).

${ }^{4}$ FTC, GENERIC DRUg ENTRY PRIOR to PATENT EXPIRATION (2002) (link); FTC, AgrEEMENTS Filed With the Federal TRade Commission Under the Medicare Prescription DrUG, IMPROVEMENT, AND MODERNIZATION ACT OF 2003: SUMMARY OF AGREEMENTS FILED IN FY 2005

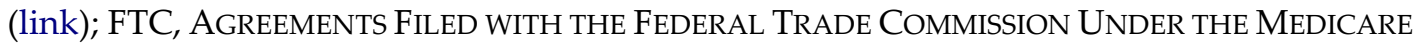
PRESCRIPTION DRUG, IMPROVEMENT, AND MODERNIZATION ACT OF 2003: SUMMARY OF AGREEMENTS FILED IN FY 2006 (link).

${ }^{5}$ The exception is Ovcon 35. See Part IV.B.1 infra. 
asserts entitlement to offer the generic drug prior to patent expiration because every relevant patent is invalid or not infringed. Moreover, other practices in the pharmaceutical industry raising potential antitrust concern are outside the study's scope, including agreements between generic firms, "product hopping," and manipulation of the FDA citizen petition and Hatch-Waxman automatic stay processes. The study presumes familiarity with the complex regulatory structure of the Hatch-Waxman Act. ${ }^{6}$

The survey proceeds in four parts. Part I provides an overview of the agreements and subsequent antitrust activity. Part II analyzes the shift over time in the mechanisms of payment and delay. Parts III and IV describe in detail the particular agreements that compose each wave of settlement.

\section{Settlements in summary}

The following pages present innovator-generic agreements in tabular form. The agreements are organized by drug, in chronological order according to the date of agreement with the first filer. For each drug, the table indicates annual sales, the parties to and major terms of each settlement, and any antitrust activity.

${ }^{6}$ For an introduction, see C. Scott Hemphill, Paying for Delay: Pharmaceutical Patent Settlement as a Regulatory Design Problem, 81 N.Y.U. L. REV. 1553 (2006) (link). 


\section{Drug}

\begin{tabular}{|c|c|c|c|c|}
\hline $\begin{array}{l}\text { Nolvadex } \\
\text { Tamoxifen citrate }\end{array}$ & $\$ 265$ m & Zeneca-Barr & Mar. 1993 & $\begin{array}{l}\text { G } \$ 66 \text { million } \\
\text { G Private label sales } \\
\text { G } 180 \text { days if revert } \\
\text { I Neutralize first filer } \\
\text { I Bottleneck } \\
\text { I Vacate adverse ruling } \\
\text { I Entry in Aug. } 2002\end{array}$ \\
\hline $\begin{array}{l}\text { BuSpar } \\
\text { Buspirone } \mathrm{HCl}\end{array}$ & $\$ 288 m$ & Bristol-Schein & Dec. 1994 & $\begin{array}{l}\text { G } \$ 73 \text { million } \\
\text { I Neutralize first filer } \\
\text { I Bottleneck } \\
\text { I Entry in Nov. } 2000\end{array}$ \\
\hline$\underset{\text { Ranitidine }}{\text { Zantac }}$ & $\$ 2150 \mathrm{~m}$ & $\begin{array}{l}\text { Glaxo- } \\
\text { Genpharm }\end{array}$ & Oct. 1995 & $\begin{array}{l}\text { G } \$ 133 \text { million } \\
\text { G } 180 \text { days } \\
\text { G Licenses outside U.S. } \\
\text { I Neutralize first filer } \\
\text { I Entry in Aug. } 1997\end{array}$ \\
\hline $\begin{array}{l}\text { Cipro } \\
\text { Ciprofloxacin }\end{array}$ & $\$ 680 \mathrm{~m}$ & Bayer-Barr & Jan. 1997 & $\begin{array}{l}\text { G } \$ 398 \text { million } \\
\text { G } 180 \text { days if revert } \\
\text { I Neutralize first filer } \\
\text { I Bottleneck } \\
\text { I Entry in Dec. } 2003\end{array}$ \\
\hline
\end{tabular}

\section{Antitrust challenges}

\section{Consumer/third party payor suit Pending petition for certiorari Below: CA2, NO}

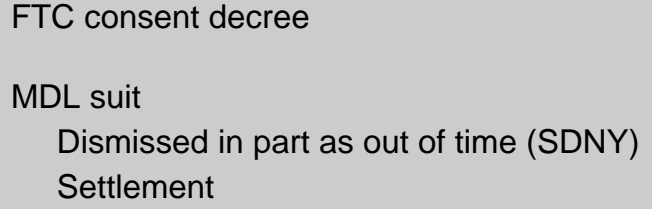

\section{MDL purchaser suit}

Pending in CA2

Below: EDNY, NO

State court suits in California, Florida, Kansas, New York, and Wisconsin All pending 


\section{Drug}

\section{K-Dur}

Potassium chloride

extended release

\section{Agreement}

Upsher

Schering-ESI

(L)

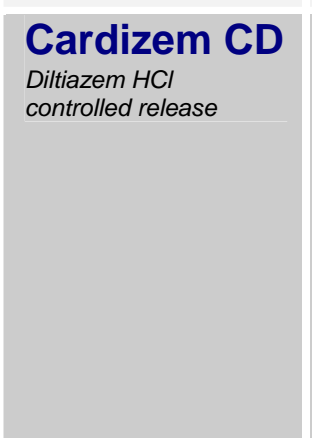

\section{Hytrin \\ Terazosin $\mathrm{HCl}$}

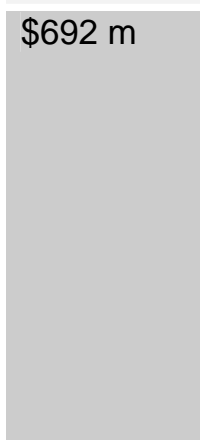

$\$ 542 \mathrm{~m}$

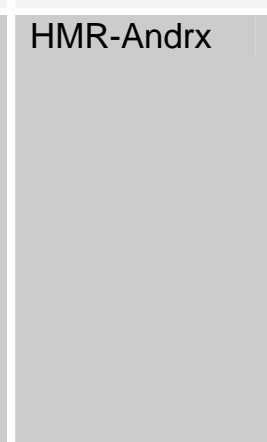

\section{Abbott- \\ Geneva}

Abbott-Zenith

(L)

Prozac
Fluoxetine $\mathrm{HCl}$

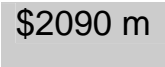

Lilly-Barr
Lilly-Geneva

June 1997

\section{G $\$ 60$ million}

G 180 days

I Neutralize first filer

I Bottleneck

I Entry in Sept. 2001

I Licenses to G's products

I Other products excluded

Jan. 1998

G \$30 million

I Entry in Jan. 2004

I Licenses to G's products

$\mathrm{G} \$ 90$ million

I Bottleneck

I No launch at risk

I Other products excluded

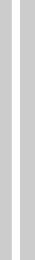

\section{Apr. 1998}

\section{G \$101 million}

I Bottleneck

I No launch at risk

I Other products excluded

Mar. 1998

G \$45 million

I Entry in February 2000

I Other products excluded

Mar. 1999
G \$4 million

G Quick appeal to CAFC

I Dismissal of two claims

I No launch at risk

\section{Antitrust challenges}

FTC consent decree (as to ESI)

FTC suit (as to Upsher)

$$
\text { CA11, NO }
$$

MDL purchaser suit

Pending in DNJ (after denying dismissal)

\section{FTC consent decree}

Competitor suit

Settled after CADC denied dismissal

Purchaser suit

$\$ 110$ m settlement with direct purchasers

$\$ 80$ m settlement with indirect purchasers, states

CA6, YES, as to nonsettling parties

\section{FTC consent decree}

MDL suit

Pending in S.D. Fla. after SJ for plaintiffs

Prior: Remand from CA11 in Valley Drug

Kaiser Foundation Health Plan suit

Pending in CA9

Below: C.D. Cal, NO 


\section{Drug}

\begin{tabular}{|c|c|c|c|c|c|}
\hline $\begin{array}{l}\text { Naprelan } \\
\text { Naproxen sodium }\end{array}$ & $\$ 59 \mathrm{~m}$ & $\begin{array}{l}\text { Elan- } \\
\text { SkyePharma }\end{array}$ & May 1999 & $\begin{array}{l}\text { G License } \\
\text { G } 180 \text { days } \\
\text { I Neutralize first filer } \\
\text { I Bottleneck }\end{array}$ & $\begin{array}{l}\text { Competitor suit } \\
\quad \text { Pending in S.D. Fla. on remand } \\
\quad \text { Prior: CA11, YES, denying dismissal } \\
\text { Purchaser suit } \\
\quad \text { Pending in E.D. Pa., stayed for competitor suit }\end{array}$ \\
\hline $\begin{array}{l}\text { Procardia XL } \\
\text { Nifedipine extended } \\
\text { release }\end{array}$ & $\$ 311 \mathrm{~m}$ & Pfizer-Mylan & Feb. 2000 & $\begin{array}{l}\text { G Private label sales } \\
\text { G } 180 \text { days } \\
\text { I Neutralize first filer } \\
\text { I Bottleneck }\end{array}$ & $\begin{array}{l}\text { Competitor suit } \\
\qquad \$ 9 \text { m settlement after dismissal denied } \\
\text { Purchaser suits } \\
\quad \text { Settled after class status denied, N.D. W. Va. }\end{array}$ \\
\hline $\begin{array}{l}\text { Ovcon } 35 \\
\text { Norethindrone and } \\
\text { ethinyl estradiol }\end{array}$ & $\$ 72 \mathrm{~m}$ & $\begin{array}{l}\text { Warner } \\
\text { Chilcott-Barr }\end{array}$ & Mar. 2004 & $\begin{array}{l}\text { G } \$ 20 \text { million } \\
\text { I Entry in May } 2009 \\
\text { I Manufacturing }\end{array}$ & $\begin{array}{l}\text { FTC suit } \\
\quad \text { Settled as to Warner Chilcott } \\
\text { Pending in D.D.C. after denial of dismissal } \\
\text { State attorneys general suits } \\
\quad \text { Pending } \\
\text { Private plaintiffs suits } \\
\quad \text { Pending }\end{array}$ \\
\hline $\begin{array}{l}\text { Niaspan } \\
\text { Niacin extended release }\end{array}$ & $\$ 380 \mathrm{~m}$ & Kos-Barr & Apr. 2005 & $\begin{array}{l}\text { G Cash } \\
\text { G } 180 \text { days } \\
\text { I Neutralize first filer } \\
\text { I Bottleneck } \\
\text { I Entry in Sept. } 2013 \\
\text { I Promotion } \\
\text { I Manufacturing }\end{array}$ & None \\
\hline $\begin{array}{l}\text { Effexor XR } \\
\text { Venlafaxine } \mathrm{HCl} \\
\text { extended release }\end{array}$ & $\$ 2275 \mathrm{~m}$ & Wyeth-Teva & Dec. 2005 & $\begin{array}{l}\text { G New product line } \\
\text { G } 180 \text { days } \\
\text { I Neutralize first filer } \\
\text { I Bottleneck } \\
\text { I Entry in July } 2010\end{array}$ & None \\
\hline
\end{tabular}




\begin{tabular}{|c|c|c|c|c|c|}
\hline Drug & US Sales & Parties & Agreeme & & Antitrust challenges \\
\hline $\begin{array}{l}\text { Provigil } \\
\text { Modafinil }\end{array}$ & $\$ 476 \mathrm{~m}$ & $\begin{array}{l}\text { Cephalon- } \\
\text { Teva } \\
\text { Cephalon- } \\
\text { Ranbaxy } \\
\text { Cephalon- } \\
\text { Mylan } \\
\text { Cephalon- } \\
\text { Barr }\end{array}$ & $\begin{array}{l}\text { Dec. } 2005 \\
\text { Dec. } 2005 \\
\text { Jan. } 2006 \\
\text { Feb. } 2006 \\
\text { Aug. } 2006\end{array}$ & $\begin{array}{l}\text { G Part of } \$ 219 \text { million } \\
\text { G } 180 \text { days } \\
\text { I Neutralize first filer } \\
\text { I Bottleneck } \\
\text { I Entry in October } 2011 \\
\text { I Intellectual property } \\
\text { I Manufacturing and supply } \\
\text { G Part of } \$ 219 \text { million } \\
\text { G } 180 \text { days } \\
\text { I Neutralize first filer } \\
\text { I Bottleneck } \\
\text { I Entry in October } 2011 \\
\text { I Intellectual property } \\
\text { I Supply } \\
\text { G Cash } \\
\text { G } 180 \text { days } \\
\text { I Neutralize first filer } \\
\text { I Bottleneck } \\
\text { I Entry in October } 2011 \\
\text { I Product development } \\
\text { G Part of } \$ 219 \text { million } \\
\text { G } 180 \text { days } \\
\text { G Actiq-specific terms } \\
\text { I Neutralize first filer } \\
\text { I Bottleneck } \\
\text { I Entry in October } 2011 \\
\text { I Intellectual property } \\
\text { I Inventory } \\
\text { I Entry in Apr. } 2012\end{array}$ & $\begin{array}{l}\text { FTC investigation } \\
\text { Purchaser suit } \\
\text { Pending in E.D. Pa. } \\
\text { Competitor suit } \\
\text { Pending in E.D. Pa. }\end{array}$ \\
\hline $\begin{array}{l}\text { Actiq } \\
\text { Oral transmucosal } \\
\text { fentanyl citrate }\end{array}$ & $\$ 395$ m & $\begin{array}{l}\text { Cephalon- } \\
\text { Barr }\end{array}$ & Feb. 2006 & $\begin{array}{l}\text { G Earlier license } \\
\text { G Share of sales in another } \\
\text { product? }\end{array}$ & FTC investigation \\
\hline
\end{tabular}




\section{Alphagan}

Brimonidine tartrate

$0.15 \%$ ophthalmic

\section{Plavix}

Clopidogrel bisulfate

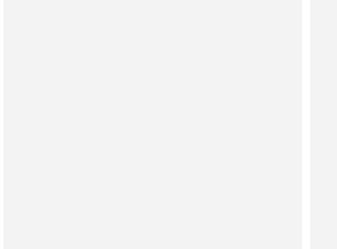

\section{Biaxin XL \\ Clarithromycin extended release}

Mixed amphetamine

salts, extended releas

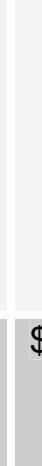

\section{US Sales Parties}

$\$ 200$ m

$\$ 3200$ m

\section{Allergan-}

Alcon

Bristol-Apotex

$\$ 864 m$
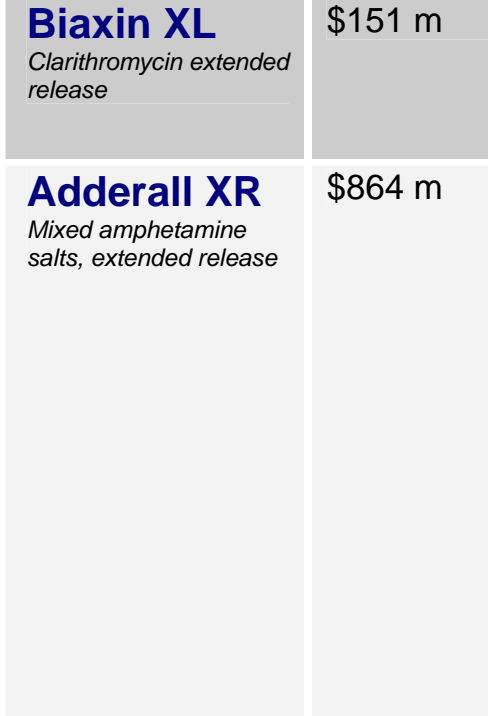

Abbott-Teva
Abbott-
Ranbaxy (L)
Shire-Barr

Shire-Barr

$x^{2}+x^{2}+x^{2}$

Shire-Impax

\section{Agreement}

Mar. 2006

May 2006

\section{$\mathrm{G} 180$ days}

G \$40 million

$\mathrm{G}$ No authorized generic?

$\mathrm{G}$ Breakup fee?

G Launch-at-risk protection

I Neutralize first filer

I Bottleneck

I Entry in Apr. 2011

I Inventory

Not fully implemented

July 2006

July 2006

Aug. 2006

Jan. 2006

\section{Antitrust challenges}

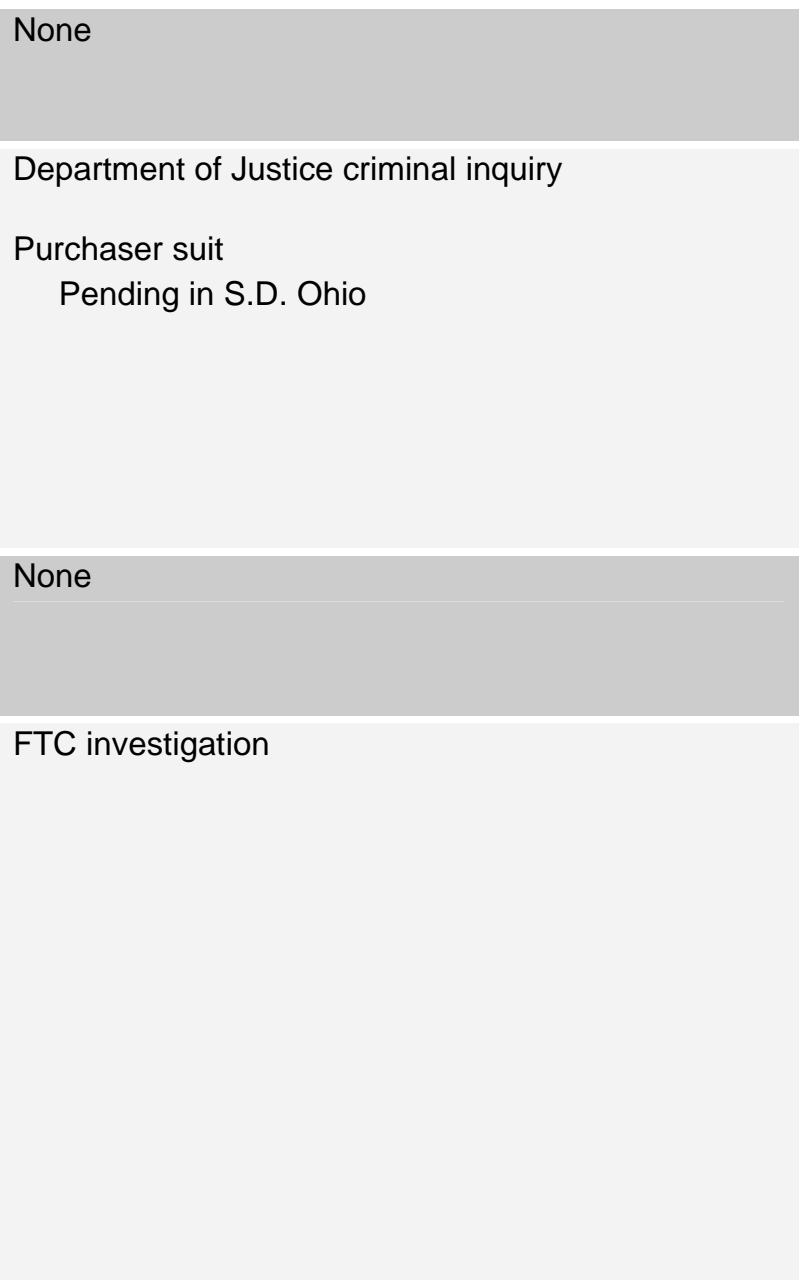




\begin{tabular}{|c|c|c|c|c|c|}
\hline Drug & US Sales & Parties & Agreemer & & Antitrust challenges \\
\hline $\begin{array}{l}\text { AndroGel } \\
\text { Testosterone gel 1\% }\end{array}$ & $\$ 330 \mathrm{~m}$ & $\begin{array}{l}\text { Solvay- } \\
\text { Watson } \\
\text { Solvay-Par (L) }\end{array}$ & $\begin{array}{l}\text { Sept. } 2006 \\
\text { Sept. } 2006\end{array}$ & $\begin{array}{l}\text { G Cash } \\
\text { G } 180 \text { days by contract } \\
\text { I Neutralize first filer } \\
\text { I Entry in Aug. } 2015 \\
\text { I Promotion } \\
\text { G } \$ 60 \text { million } \\
\text { I Entry in Feb. } 2016 \\
\text { I Promotion } \\
\text { I Backup manufacturing }\end{array}$ & None \\
\hline
\end{tabular}


As the chart demonstrates, settlements occur in drugs with a wide range of sales. The study includes a few blockbusters, including Zantac ( $\$ 2.2$ billion in U.S. sales in 1995) and Plavix ( $\$ 3.2$ billion, 2005), a few quite minor drugs such as Naprelan (\$59 million, 1999), and many in the sub-blockbuster range, that is, hundreds of millions of dollars in annual sales. ${ }^{7}$ Several of the drugs are extended release or controlled release successors to existing drugs, such as KDur, Cardizem CD, Procardia XL, Effexor XR, Biaxin XL, and Adderall XR.

A wide range of firms have entered into the settlements, seventeen innovators and eighteen generic firms in all. The summary figures disguise some complications. For example, Kos and Abbott are counted separately, though Kos is now part of Abbott. Nor do the figures include multiple parties on one side of a transaction. As noted in the Introduction, a few generic firms appear repeatedly, particularly Barr.

For seven drugs, the innovator reached agreement with multiple generic firms. A few of these settlements are with multiple generic firms, each of which has first-filer status, and thus shares in potential entitlement to generic exclusivity. In the case of Provigil, for example, Cephalon settled with four different firms that each filed on the first possible day and therefore shared in potential entitlement to the exclusivity period. Other settlements are with a generic firm the filed later and thus lacked entitlement; these settlements are marked "( $\mathbf{L})$ " in the chart.

The agreed-upon entry date varies widely. Many first-wave settlements, including tamoxifen, BuSpar, Zantac, and Cipro, provided for entry only upon expiration of the relevant patent protection. Second-wave settlements generally provide for a pre-expiration entry date. This was an innovation of the K-Dur settlements, part of the first wave, that has been widely adopted in second-wave agreements. For some settlements, the pre-expiration entry date is very close to expiration - in the case of the Plavix settlement, for example, eight months before. Others are earlier, as with Niaspan's agreed-upon entry in 2013, four years before patent expiration. Pre-expiration entry may nevertheless be at or after the end of the drug's period of profitability, due to the pre-expiration onset of generic competition in a competing therapy, the arrival of a superior,

7 In most cases, the sales figure used is company sales in the United States in the year of settlement. In some cases, this figure was unavailable and a different estimate was used. See Parts III and IV for details. 
competing brand-name drug, or the innovator's own plans to shift customers to a line extension or next-generation therapy.

Other settlement terms also vary widely, but their discussion is deferred to Part II; nevertheless, three clarifications of the chart may be useful. Terms benefiting the generic firm are marked " $G$ ", and those benefiting the innovator are marked "I". As for cash, where the public information indicates a range of cash payments, only the maximum is reported in the chart. Finally, in some settlements, the generic firm sells innovator-provided product under the generic firm's label. In others, the opposite occurs, and the generic firm provides product to the innovator. The term "supply agreement" is sometimes used to describe both practices. In this survey, only the generic firm's provision of product to the innovator is called a supply agreement; an innovator's provision of product to the generic firm is called "private label sales."

These settlements have attracted a great deal of antitrust activity, including private suits and agency investigations, consent decrees, and litigation. As noted in the introduction, ten drugs have pending activity. In a number of the challenges, a court has expressed a view about the merits, and this is indicated in the chart in a rough manner by "NO" (a ruling against antitrust liability) or "YES" (a ruling in favor of liability).

\section{The mechanisms of payment for delay}

The settlements share a basic structure. In each, a generic firm seeks to market a generic version of an innovator's drug prior to the expiration of the innovator's patent protection on the drug. ${ }^{8}$ The innovator, rather than take the chance that it might lose the suit, agrees to confer compensation upon the generic firm. The generic firm agrees to abandon its challenge and to delay entry.

The settlements vary considerably, however, in the forms of payment and delay. This Part draws upon the detailed accounts of each settlement provided in Part III to explain the forms that compensation and delayed entry may take. In this discussion, two common settlement terms are ignored and not discussed further: provisions that accelerate the generic launch date if another generic firm enters the market, and royalties paid by the generic firm upon its negotiated launch date.

\footnotetext{
${ }^{8}$ With the exception of Ovcon 35, where no patent was at issue.
} 


\section{A. Compensation to the generic firm}

The settlements in the study suggest three principal ways in which an innovator can pay a generic firm. It can pay cash, including overpayment for goods and services provided by the generic firm. It can act to preserve a firstfiling generic firm's access to the lucrative 180-day period of generic exclusivity. And it can set a very low price for goods and services provided to the generic firm. Aside from these mechanisms, a few settlements may confer compensation that defies neat classification.

\section{Cash and overpayment}

The amount of cash paid varies greatly across the settlements. The Cipro settlement features the largest cash payment, \$398 million. Other settlements with cash transfers exceeding $\$ 100$ million $^{9}$ include Provigil (\$219 million), Zantac (\$133 million), and Adderall XR (\$102 million). ${ }^{10}$ Six more have cash payments in the $\$ 10$ million to $\$ 100$ million range, including BuSpar ( $\$ 73$ million), tamoxifen ( $\$ 66$ million), K-Dur ( $\$ 60$ million to the first filer and $\$ 30$ million to a later filer), Hytrin ( $\$ 45$ million to a later filer), and Ovcon 35 (\$20 million). In addition, the two "interim" settlements in the study included large cash payments. ${ }^{11}$

These figures must be used with care. The size of cash compensation is often absent in public data altogether or as to particular deal components. Moreover, focusing only on cash provides an incomplete and misleading picture of compensation. Such a single-minded approach ignores other important forms of compensation to a generic firm, including preservation of exclusivity and a low transfer price.

Focusing on cash also makes it tempting to rely upon economically incorrect "safe harbors." For example, the fact that a cash payment is smaller than the litigation expense saved by settling-even if none of the other forms of compensation is present-does not itself render a payment procompetitive.

\footnotetext{
${ }^{9}$ The totals are for the year or years paid, so the figures are not precisely comparable. In some cases, the cash figure represents a maximum under the agreement. See Part III for details.

${ }^{10}$ The Provigil figure aggregates multiple agreements with first-filers. The Adderall XR figure is the net result of a complex set of transfer payments. See Part III for details.

${ }^{11}$ Interim settlements do not resolve the litigation but merely block entry pending its resolution. The Cardizem CD interim settlement provided for a $\$ 90$ million payment. The Hytrin interim settlement with a first filer provided for a $\$ 45$ million payment.
} 
After all, both sides have litigation expense that they conserve by settling. Ordinarily, each party could simply pocket the saved expense, rather than one party paying the other. When the innovator pays the generic firm the entire amount of the innovator's saved expense, this can constitute payment for additional delay.

Evaluation of the cash component is complicated by the presence of simultaneous side deals. In first-wave settlements, such as tamoxifen, BuSpar, Zantac, and Cipro, the absence of a side deal made it relatively straightforward to conclude that the cash payment provided compensation for the generic firm's delayed entry. Second-wave settlements, by contrast, often feature a complex set of contemporaneous transactions in which the generic firm provides additional value, apart from the agreement to delay entry.

The earliest example of this development is actually a first-wave settlement, an agreement that drug maker Schering entered into with a generic rival with respect to the potassium replacement drug K-Dur. In exchange for cash, the first filing generic firm agreed both to delay entry and to supply licenses to other products. ${ }^{12}$ The FTC's antitrust case challenging the agreement turned in part upon whether the cash payment made by Schering was consideration for the rival's delay or its licenses. One of the Eleventh Circuit's grounds for denying antitrust liability was its conclusion that the innovator's payment was consideration for the licenses.

It comes as no surprise, then, that side deals have been widely adopted in second-wave settlements. In general, the additional value provided by the generic firm is not something that the innovator had sought from the generic firm prior to the overall settlement, a signal that its value is low. Side deals take four principal forms.

Intellectual property and product development. The generic firm agrees to license its own intellectual property or to develop new products for sale by the innovator. The K-Dur settlement described above is an early example. Three of Cephalon's agreements with first-filing firms to settle Provigil patent suits include payments described as compensation for intellectual property. A fourth agreement includes a product development term. Similarly, one of the

\footnotetext{
III.A.5 infra.
}

${ }^{12}$ Schering subsequently reached a similar deal with a later filing generic firm. See Part 
agreements settling Adderall XR patent litigation includes a provision that the generic firm will help develop additional products.

Manufacturing and supply. The generic firm agrees to provide manufacturing services or supply product to the innovator. The Ovcon 35 and Niaspan settlements include such a term, as do two of the Provigil settlements (a manufacturing and supply term as to generic firm Teva, supply only as to Ranbaxy). In the Adderall XR settlement described above, the generic firm agreed to provide manufacturing as to products that might emerge from the development agreement. One of two AndroGel settlements features a variation in which the generic firm provides "backup" manufacturing services.

Inventory. The generic firm agrees to provide its existing inventory of the drug. Agreements with inventory purchase terms include Cephalon's Provigil settlement with Barr and Bristol's Plavix settlement, never fully implemented, with Apotex.

Promotion. The generic firm agrees to promote the innovator's product. This is a term in the Niaspan settlement and both AndroGel settlements. In those settlements, the generic firm agreed to promote the product at issue in the litigation. In one of the Adderall XR settlements, the generic firm agreed instead to promote an unrelated product.

\section{Preserving exclusivity}

In many settlements, the generic firm retains eligibility for the 180-day exclusivity period, by agreeing to enter at a particular future date that is at least 180 days prior to patent expiration. Many settlements include this feature, including K-Dur, Naprelan, Procardia XL, Niaspan, Effexor XR, Provigil (as to each of four first-filers), Plavix, and Adderall XR. ${ }^{13}$ Retained exclusivity is a form of compensation worth hundreds of millions of dollars for a major drug. ${ }^{14}$

The reason why retained exclusivity is valuable is somewhat subtle. Because the patent is never adjudicated, the generic firm does not risk the possibility that it might lose the patent suit. If the generic firm lost, it would be forced to wait until patent expiration - but more than that, it would lose the 180day entitlement. By reaching an agreement on entry dates, the generic firm information.

${ }^{13}$ In a few cases, retained exclusivity cannot be confirmed based upon available public

${ }^{14}$ In addition, AndroGel appears to have retained exclusivity by contract. 
retains the entitlement, turning the mere probability of enjoying it (if it won the patent suit) to a near certainty. The generic firm is not absolutely certain of enjoying exclusivity because, for example, a later-filing generic firm might win a patent suit, triggering the first-filer's exclusivity period prior to the first filer's FDA approval. But assurance of non-interference from the innovator is still very valuable to a generic firm.

A generic firm can even make money from the exclusivity period when it does not actually enter, by insisting upon compensation from a later-filing generic firm as a condition for relinquishing its exclusivity and permitting the later filer to enter. (This is a consequence of the "bottleneck"; see Part II.B.2 for a discussion.) The generic firm in the Zantac settlement, for example, made money in this way. Although the firm did not enter, it accepted payment in exchange for allowing another firm's entry.

A related source of compensation is for the innovator to agree not to launch an "authorized generic" version of the product. The authorized generic issue arises when an innovator, faced with competition from a first-filing generic firm, recruits an additional generic firm to sell an unbranded version of the drug under the innovator's own license. The presence of an authorized generic reduces the value of the generic firm's exclusivity period. In some settlements, including Adderall XR and Plavix, the innovator agrees not to launch an authorized generic. ${ }^{15}$ Such forbearance increases the value of exclusivity, potentially by a large amount. Thus an agreement to forgo an authorized generic, like retained eligibility itself, is a means to pay for delay.

Two other settlements, tamoxifen and Cipro, contain a weaker version of retained exclusivity. Both settlements provided that the generic firm would wait to enter until patent expiration, and the generic firm - in both cases Barr - altered its ANDA from paragraph IV to paragraph III. ${ }^{16}$ But in each case, faced with the possibility of pre-expiration generic entry by other firms, Barr converted back from paragraph III to paragraph IV and asserted its continued entitlement to the exclusivity period.

Not all settlements include guaranteed exclusivity. This term may be missing for several reasons. First, the agreement may provide for no entry until

\footnotetext{
15 There were two Plavix agreements. The initial agreement included the term; the parties disagree about whether the revised agreement included the term. See Part IV.A.5 infra.

${ }^{16}$ In the tamoxifen settlement, there was limited generic entry in the form of private-label sales, as discussed in the next section.
} 
patent expiration. Second, the agreement may not resolve the patent dispute, in which case the generic firm receives no assurance of being able to enjoy the exclusivity period. That was the case in the "incomplete" agreements-Hytrin, Cardizem CD, and Prozac-discussed in Part III.B. Third, some settling generic firms have no eligibility for exclusivity. This is true of later filers, such as the secondary settlements in Hytrin, K-Dur, Provigil, Adderall XR, and AndroGel. It is also true for first filers, where the applicable procedure provides no basis for exclusivity-for example, because there is no patent for the first filer to challenge, as in Ovcon 35, or because the particular procedure used for innovator approval does not allow for exclsuivity, as with Biaxin $\mathrm{XL}$, or because the generic firm uses a procedure that does not provide for an exclusivity period, as with Alphagan. For a discussion of these settlements, see Part IV.B.

A final reason that might seem to undermine retained exclusivity turns out not to matter. The Medicare Modernization Act of 2003 limits the ability of a settling generic firm to retain eligibility by providing for forfeiture if the parties settle, but that provision does not apply to settlements resulting from ANDAs filed before the effective date of the Act. ${ }^{17}$ Of the settlements in the survey in which the generic firm had potential eligibility for the exclusivity period, all but one are covered by the pre-MMA rules. ${ }^{18}$ In the single exception, Actiq, the generic firm had no practical prospect of receiving the exclusivity period. ${ }^{19}$

\section{Underpricing}

Compensation may also be conferred by choosing a low price for goods transferred from the innovator to the generic firm. For example, the parties may arrange for private label sales, in which the innovator provides product that the generic firm sells under its own brand. The tamoxifen and Procardia XL

${ }^{17}$ See Medicare Prescription Drug, Improvement, and Modernization Act of 2003, Pub. L. No. 108-173, 177 Stat. 2066. The new forfeiture regime, 21 U.S.C. $§ 355(j)(5)(D)$ (Supp. 2004), applies only to ANDAs filed after December 8, 2003, where no previous ANDA-IV was filed earlier than December 8. See § 1102(b) of the Act, 117 Stat. 2460.

${ }^{18}$ Barr's ANDA in Actiq was filed after the new rules took effect. The forfeiture provisions do not apply to settlements for which the exclusivity period was never available. For settlements reached before MMA passage, the related ANDA filings occurred even earlier and are governed by the pre-MMA rules. Of the post-MMA settlements, all but Actiq had pre-MMA ANDA filings: Niaspan (October 2001 and March 2002); Effexor XR (March 2003); Provigil (December 2002); Plavix (November 2001); Adderall XR (November 2002); and AndroGel (May 2003).

${ }^{19}$ Barr's ANDA-IV in Actiq was filed sufficiently late as to leave little time to win a suit and enjoy the exclusivity period prior to patent expiration. See Part III for details. 
settlements, for example, contain such a term. A private label deal, if it includes a low transfer price, permits net payment from an innovator to a generic firm. License terms are not public, so it is difficult to assess the extent of this practice.

Underpriced transfers are the flip side of overpriced side deals. For side deals, the concern is that the parties attribute an unrealistically high price to the value provided by the generic firm. For transfers, the concern is that the parties agree to an unduly low price for value provided by the innovator.

The transfer can extend to additional products not directly at issue, as in the Effexor XR and Adderall XR settlements. In both settlements, the innovator secured an agreement to delay entry in the newer extended-release version of the drug, but arranged for immediate generic use of the older immediate-release version. In the case of Effexor, this took the form of a product license; in Adderall, a sale of rights. Similarly, the private label sales in the Procardia XL settlement included dosage forms for which the generic firm was not the first filer. Again, the extent of compensation is difficult to evaluate with public information.

\section{Additional channels}

The innovator and generic firm may be adversaries in other disputes, the settlement of which can confer compensation upon the generic firm. For example, the Zantac settlement resolved patent litigation in other countries. Cephalon and Barr settled litigation involving two drugs, Provigil and Actiq, at the same time.

A further, unusual form of compensation is described in the most recent FTC settlement report (emphasis added):

The remaining case also had no explicit restriction on generic entry. It involved a complex set of transactions in which the brand manufacturer granted the generic company a license to an authorized generic of the capsule form of the product that was the subject of the litigation; the brand company acquired a new tablet form of the product at issue; the brand agreed to pay the generic a royalty on the sales of the acquired product; and then the parties dismissed the litigation involving the capsule form of 
the product. As one of the parties has disclosed, this set of transactions is under investigation by the FTC. ${ }^{20}$

If this description is correct, the innovator agreed to pay the generic firm a royalty on a different form - the new form - rather than the form actually at issue in the litigation. This unusual feature may have been a part of the Actiq settlement between Cephalon and Barr. (For further discussion, see Part IV.A.4.)

\section{B. Delay in generic entry}

The delay in generic entry takes four principal forms: by neutralizing the challenge by the firm most motivated to test the innovator's patent protection; by creating a bottleneck that prevents FDA approval of later filers; by heading off entry during the period while a patent suit is pending; and through application to products not directly at issue in the litigation. ${ }^{21}$

\section{Neutralizing the first filer}

In most settlements with first filers, the settlement has the effect of neutralizing the single firm with eligibility for exclusivity. Generic firms other than the first filer will lag behind in the approval process, if they have bothered to file at all; they will also be less motivated to initiate or vigorously pursue a challenge to the innovator's patents. The settlement removes from consideration the most motivated challenger, and the one closest to introducing competition.

\section{Bottleneck}

In some settlements, the entry of subsequent filers can be blocked entirely due to a statutory bottleneck created by the Hatch-Waxman regime. The 180-day exclusivity period operates by delaying FDA approval of a later-filing generic firm's ANDA-IV. In particular, the statute requires that a later-filed ANDA-IV not be approved until 180 days after the first filer's initiation of commercial marketing or a court determination of invalidity or noninfringement, whichever comes first. A settlement between the first ANDA-IV filer and the innovator removes an opportunity for commercial marketing or a court determination. Without the occurrence of either triggering event, the later ANDA-IV filer is stuck, for the FDA lacks authority to approve the application. The block is

${ }^{20}$ FTC, FY 2006 Report, supra note 4.

${ }^{21}$ In one settlement, tamoxifen, the parties also agreed to vacate a ruling adverse to the innovator. 
incomplete: if a later ANDA filer wins a favorable court decision, that decision triggers the exclusivity period - that is, the first filer's exclusivity period. The subsequent ANDA filer could enter 180 days later.

In a few first-wave settlements, such as tamoxifen, BuSpar, and Cipro, the generic firm relinquished exclusivity eligibility by changing its certification from paragraph IV to paragraph III. In the case of tamoxifen and Cipro, however, this did not entirely remove the bottleneck, for upon the emergence of other potential generic entrants, the generic firm (in both cases, Barr) reasserted continued entitlement to the exclusivity period.

\section{Interim delay}

In two settlements (Cardizem CD and Hytrin), the delay in entry took the form of a commitment not to launch "at risk" - that is, after FDA approval of generic entry, but before complete certainty emerged that the patent was invalid or not infringed. For example, when an innovator sues a generic firm for patent infringement, an automatic stay is entered that prevents generic entry for thirty months or more. Sometimes, however, the automatic stay expires before the district court has decided the patent suit, in which case FDA approval may be granted and the product launched despite the absence of a ruling. In that event, a commitment by the generic firm not to launch at risk can be a valuable interim benefit to an innovator. Moreover, in Hytrin the generic firm agreed to stay out even after the district court ruled in its favor, and the risk had significantly subsided.

\section{Agreement as to noninfringing products}

In several settlements, the agreement prevented entry not only as to the product directly at issue in the generic firm's ANDA, but other competing products as well. This was true of one of the K-Dur settlements, the Cardizem CD settlement, and both Hytrin settlements. The FTC and courts attacked this term as clearly outside the scope of the innovators' patents. Second-wave settlements omit this term.

\section{First-wave settlements}

This Part and the next provide detailed accounts of each settlement, drawn from court filings, press releases, news accounts, and, in a few cases 
where they have been made public, the actual agreements. ${ }^{22}$ This Part describes first-wave settlements, organizing them according to whether the settlement fully resolves the underlying patent litigation. Settlements for seven drugs do so, and three do not.

\section{A. Complete settlements}

\section{Tamoxifen}

Tamoxifen citrate, sold by Zeneca under the brand name Nolvadex, is the "most prescribed cancer drug in the world." ${ }^{23}$ Nolvadex's U.S. sales in 1992 totaled $\$ 265$ million, which rose to $\$ 442$ million in 2001, the last full year of sales prior to generic entry. ${ }^{24}$

Zeneca ${ }^{25}$ and first-filer Barr reached agreement in March 1993.26 Zeneca agreed to pay \$66.4 million: \$21 million to Barr, and \$9.5 million immediately and \$35.9 million over ten years to Barr's raw materials supplier Heumann. In addition to cash, Barr received compensation through profitable private-label sales. Zeneca allowed Barr to sell Zeneca-made tamoxifen under Barr's label. The licensed version sold at a 15 percent discount to Zeneca's version. Barr soon captured most of the market.

The amount of compensation provided by the private-label arrangement is difficult to determine using public information. Its value may be indicated, however, by the different course taken in the Cipro settlement. There, the innovator had the option to implement a similar supply agreement, but chose instead to simply make large cash payments.

Barr also retained potential entitlement to the exclusivity period, without fear of losing it by losing a patent suit. Barr initially changed its Paragraph IV

22 See, e.g., Defendants' Notice of Submission of Zenith Settlement Agreement, Kaiser Found. v. Abbott Labs., No. 2:02cv2443 (C.D. Cal. Mar. 14, 2006) [hereinafter Hytrin Zenith-Abbott Agreement]; Barr Pharmaceuticals 10-Q, supra note 2, Exhs. 10.1, 10.2, and 10.3 [hereinafter Adderall XR Agreement]; Bristol-Myers Squibb, Quarterly Report (Form 10-Q), Exhibits 99.1, 99.2 (link) (Aug. 8, 2006) [hereinafter Plavix Agreement].

${ }^{23}$ In re Tamoxifen Citrate Antitrust Litig., 466 F.3d 187, 193 (2d Cir. 2006).

${ }^{24}$ See Zeneca Settles US Patent Dispute, Pharma MarKetLetTer, Mar. 22, 1993 (1992 sales); Tamoxifen, 466 F.3d at 193 n.1 (2001 sales).

${ }^{25}$ Zeneca succeeded to ICI's rights and later became part of AstraZeneca.

${ }^{26}$ See Tamoxifen, 466 F.3d at 193-96, 194 n.9. 
certification to Paragraph III, thereby certifying that it would wait to enter until patent expiration. Yet Barr later reverted to a Paragraph IV certification, and asserted its continued entitlement to the 180-day exclusivity period when generic firm Mylan gained FDA's tentative approval to market a generic product.

From Zeneca's standpoint, the settlement neutralized the first-filer threat, by removing from litigation the single firm, Barr, with entitlement to the 180-day exclusivity period. The settlement also created a partial bottleneck, in the sense that Barr's reversion to a paragraph IV assertion limited the prospect for approval of later filers. Barr agreed to enter with its own ANDA product until August 2002, when a key Zeneca patent expired. ${ }^{27}$ Generic manufacturers entered soon after the expiration of the patent. One further unusual feature of the agreement is that the parties agreed to seek vacatur of the district court's ruling that the relevant patent was invalid. The Federal Circuit granted vacatur. ${ }^{28}$

The tamoxifen settlement has attracted numerous antitrust challenges, including 33 purchaser class action complaints. ${ }^{29}$ In 2006, the Second Circuit dismissed on the merits. ${ }^{30}$ As of March 2007, a petition for certiorari was pending. ${ }^{31}$

\section{BuSpar}

Buspirone hydrochloride, sold by Bristol-Myers Squibb under the brand name BuSpar, is a widely prescribed antianxiety drug. BuSpar's U.S. sales in

\footnotetext{
${ }^{27}$ U.S. Patent No. 4,536,516.

${ }^{28}$ Imperial Chem. Indus., PLC v. Heumann Pharma GmbH, 1993 WL 118931 (Fed. Cir. 1993).

${ }^{29}$ See Barr Pharmaceuticals 10-Q, supra note 2.

${ }^{30}$ In re Tamoxifen Citrate Antitrust Litig., 466 F.3d 187 (2d Cir. 2006).

${ }^{31}$ Petition for Writ of Certiorari, Joblove v. Barr Labs, Inc., 2006 WL 3694387; see also

Brief for 41 Professors of Economics, Business and Law as Amici Curiae in Support of Granting the Petition, 2007 WL 527488; Brief for the American Antitrust Institute as Amicus Curiae in Support of Petitioners, 2007 WL 518366; Brief for National Association of Chain Drug Stores as Amicus Curiae in Support of Petitioners, 2007 WL 518365. The petition is scheduled for consideration at Conference on Mar. 16, 2007; see Docket No. 03-7641 (link).
} 
1995 totaled $\$ 288$ million, which rose to more than $\$ 600$ million in 2000, the year prior to generic entry. 32

Bristol and first-filer Schein reached agreement in December 1994..$^{33}$ Bristol paid Schein $\$ 72.5$ million in four installments. Retained exclusivity was not a source of compensation to Schein, as no entry was contemplated prior to patent expiration.

From Bristol's standpoint, the settlement neutralized the first-filer threat. The settlement also created a bottleneck: later ANDA-IV filers could not receive FDA approval until 180 days after entry of a first filer with exclusivity eligibility, so Schein's continued presence as a first filer blocked approval of later-filed ANDAs. Schein agreed to wait to enter with its own product until November 2000, when the key patent expired..$^{34}$

The BuSpar settlement attracted numerous antitrust challenges. The FTC challenged the settlement, culminating in a consent decree in 2003 that covered this and other allegedly anticompetitive activities by Bristol. ${ }^{35}$ (This consent decree played an important role in the later Plavix settlement; see Part IV.A.5.) A variety of private suits were filed and consolidated as multidistrict litigation in a New York district court. In 2002, the district court dismissed the suit as to competitors and in part as to purchasers, due to expiration of the limitations period. ${ }^{36}$ In 2003, Bristol reached a settlement with state plaintiffs to resolve this and other claims. ${ }^{37}$

32 See Annual Report: Top 100 Drugs: Antianxiety Medicines, Med AD News, May 1, 1996, available at 1996 WLNR 4441128 (1995 sales); FTC, Analysis to Aid Public Comment, In re BristolMyers Squibb Company (link) (2000 sales).

33 See Analysis to Aid Public Comment; FTC report (noting payment in installments).

${ }^{34}$ U.S. Patent No. 4,182,763. This was not the end of the story; generic entry was delayed further by a dispute over a later-issued patent on metabolite.

${ }^{35}$ In re Bristol-Myers Squibb Co., No. C-4076, 2003 WL 21008622 (F.T.C. Apr. 14, 2003); see also Analysis to Aid Public Comment.

${ }^{36}$ In re Buspirone Patent Litig., 185 F. Supp. 2d 363 (S.D.N.Y. 2002) (MDL-1410).

${ }^{37}$ The settlement reportedly totaled $\$ 100$ million for consumers in most states and state agencies, and another $\$ 90$ million for third-party payors and consumers in the remaining states. See Patrick E. Cafferty, Indirect Purchaser Class Action Settlements, American Antitrust Institute Working Paper No. 06-05 (June 2006). 


\section{Zantac}

Ranitidine, sold by Glaxo under the brand name Zantac, is an antiulcerant. Zantac was the world's best-selling prescription medicine in 1995, with U.S. sales of $\$ 2.15$ billion. ${ }^{38}$

To understand the settlement that resulted, it is necessary to review briefly the underlying patent suit. Two forms of ranitidine, "Form 1" and "Form 2, , and two patents, are particularly relevant. At the time of the Zantac settlement, Form 1 ranitidine had never been made commercially and was considered relatively difficult to manufacture. Form 2 was the form actually used by Glaxo. The two forms are bioequivalent. Form 1 was protected by a patent that expired in July 1997. ${ }^{39}$ Form 2 was protected by a patent that expired in December 2002.40 First-filing generic firm Genpharm ${ }^{41}$ sought to make a Form 2 product prior to patent expiration, and challenged not only the validity of the Form 2 patent, but also - and this was an unusual feature of the challenge - the validity of the basic Form 1 patent. The case was scheduled for a jury trial in October $1995 .^{42}$

Glaxo and Genpharm reached agreement in October 1995, on the eve of trial. ${ }^{43}$ Glaxo likely paid Genpharm $\$ 132.5$ million, a figure not publicly disclosed but inferred from an FTC report. ${ }^{44}$ Genpharm retained entitlement to

38 See Annual Report: Top 100 Drugs: Histamine H(2) Receptor Antagonists, MED AD News, May 1, 1996, at 1, 36, available at 1996 WLNR 4446118.

${ }^{39}$ U.S. Patent No. 4,128,658.

${ }^{40}$ U.S. Patent No. 4,521,431. The original expiration was June 2002, but this was extended.

${ }^{41}$ Genpharm was and is a subsidiary of the E. Merck Generics Group of Merck KgaA.

${ }^{42}$ See Glaxo Wellcome PLC Further re Patent Litigation, July 10, 1995; cf. Granutec Inc. v. Shalala, 46 U.S.P.Q.2d 1398 (4th Cir. 1998) (describing the suit but erroneously asserting that Glaxo "prevailed," as opposed to settling, in October 1995). The relevant docket for the patent suit appears to be District of Maryland, Nos. 92-1831 and 93-4228.

${ }^{43}$ See Granutec, 46 U.S.P.Q.2d at 1403, 1405 (describing the waiver of 180-day eligibility, characterizing it as "quite lucrative," and noting entry); Press Release, Glaxo Wellcome PLC, Glaxo Wellcome PLC Re Genpharm Litigation (Oct. 23, 1995) (describing license in other markets).

${ }^{44}$ Zantac is likely Drug Product I in the 2002 FTC report. Product I is the only drug listed in the relevant FTC table whose sales (like Zantac's) exceeded $\$ 1$ billion in the year of agreement. The agreement involving Product I included a delay of one year, nine months, which matches the delay between the Zantac agreement (in October 1995) and the expiration of the first patent in issue ('658, in July 1997). The agreement involving Product I resolved patent litigation in other countries, an unusual feature of the agreement. Similarly, the Glaxo-Genpharm pact settled Zantac litigation outside the United States. Drug Product I fits none of the other cases that have 
the exclusivity period, without fear of losing it by losing a patent suit, and received compensation, including a profit-sharing agreement, when it later waived exclusivity in favor of subsequent filer Granutec. ${ }^{45}$ A federal appeals court described the transaction as "quite lucrative." Glaxo granted Genpharm and related companies licenses and supply agreements to sell a generic version of Zantac in several other countries.

From Glaxo's standpoint, the settlement neutralized the first-filer threat. This was particularly important because Genpharm's challenge to the basic Form 1 patent was an unusual threat. The settlement did have a bottleneck potential, but Genpharm waived exclusivity in favor of Granutec in exchange for payment. Genpharm agreed to wait to enter with a Form 1 product until the Form 1 patent expired in July 1997 and to wait to enter with a Form 2 product until 2002. ${ }^{46}$ The Form 2 restriction was significant because in 1995 it had not been established that a Form 1 product could be made without infringing the Form 2 patent, and Glaxo argued strongly (though ultimately unsuccessfully) to the contrary. Moreover, Form 1 had not yet been made in commercial quantities. Generic entry by Novopharm began in August 1997. The agreement also resolved patent litigation in other countries.

As the Financial Times described the Zantac settlement at the time, "With so much at stake, the fact that Glaxo is having to pay Genpharm to turn it from a competitor into a distributor is money well spent." ${ }^{47}$ The settlement attracted no antitrust challenges.

received antitrust attention from the FTC or private parties. At the time of the settlement, Glaxo described the amount of settlement as "not material," but a \$132.5 million payment would not be considered material for a company as large as Glaxo. If Zantac is indeed Drug Product I, then the Zantac settlement, according to the FTC Report, entailed a payment of \$132.5 million.

${ }^{45}$ Granutec, a subsidiary of Novopharm, expected \$150 to \$200 million in sales from a one-month lead (part of the exclusivity period had expired) before other generic firms entered. Sandra Rubin, Novopharm Gets Zantac Deal, FIN. POsT, Aug. 5, 1997 (“'It's a major coup for us,' said Novopharm chairman Leslie Dan. 'In two weeks we can literally blanket the U.S. market. And history tells us that whoever enters the market first will usually end up as the major supplier of the product for many, many years.'”). Novopharm also paid Glaxo more than $\$ 70$ million for a related license. $I d$.

${ }^{46}$ It appears that at the time of settlement, Genpharm had no ANDA filed on Form 1. See 46 U.S.P.Q.2d 1398 (noting 1996 filing of Genpharm ANDA-IV for Form 1).

${ }^{47}$ See Soothing Glaxo's Ulcers, FIN. TIMES, Oct. 24, 1995, at 20. 


\section{Cipro}

Ciprofloxacin, sold by Bayer under the brand name Cipro, is an antibiotic. Cipro was the most widely prescribed quinolone in 1995, with U.S. sales in 1996 of $\$ 680$ million..$^{48}$

Bayer and first-filer Barr ${ }^{49}$ reached agreement in January 1997. ${ }^{50}$ Bayer paid Barr $\$ 398$ million by December 2003: $\$ 49.1$ million initially, followed by quarterly payments. Although the agreement provided for private label sales along the lines of the tamoxifen agreement, this provision was not implemented. Bayer exercised its option under the agreement to pay cash instead.

As with the tamoxifen agreement, Barr retained potential entitlement to the exclusivity period, without fear of losing it by losing a patent suit. Barr initially changed its Paragraph IV certification to Paragraph III, thereby certifying that it would wait to enter until patent expiration. Yet Barr later reverted to a Paragraph IV certification, and asserted its continued entitlement to the 180-day exclusivity period.

From Bayer's standpoint, the settlement neutralized the first-filer threat. The settlement also created a partial bottleneck, in the sense that Barr's reversion to a paragraph IV assertion limited the prospect for approval of later filers. Barr agreed to wait to enter until December 2003, when the relevant Bayer patent expired. ${ }^{51}$

The Cipro settlement attracted numerous antitrust challenges. Twentyfour class action complaints were consolidated in multidistrict litigation. ${ }^{52}$ In 2005, the district court granted summary judgment to defendants. As of March 2007, appeal in the Second Circuit was pending. Defendants have moved that

${ }^{48}$ See Bayer Group Reports net earnings of $\$ 1.67$ bil in 1995, up 21.5\% vs 1994, MED AD NEwS, Sept. 1, 1996 (most widely prescribed qunolone); Glaxo's \$5.8B in Revs Tops List of Drug Makers, SEleCt Federal FILINGS NeWSWIRES, Feb. 14, 1997 (U.S. sales); see also Cipro Global Sales of the Quinolone Cipro (Ciprofloxacin) Totalled $\$ 1.29$ Bil in 1996, up 11.1\% vs 1995, MED AD News, May 1, 1997 (worldwide sales of $\$ 1.29$ billion).

${ }^{49}$ Barr recruited generic firm Rugby to share in the costs and profits of the litigation. Rugby was a subsidiary of Hoechst Marion Roussel at the time of the agreement, but was subsequently purchased by generic firm Watson.

${ }^{50}$ In re Ciprofloxacin Hydrochloride Antitrust Litig., 363 F. Supp. 2d 514, 519-20

(E.D.N.Y. 2005).

${ }^{51}$ U.S. Patent No. 4,670,444.

52 See id.; notice of appeal filed, Nos. 05-2851, -2852 (2d Cir. June 7, 2005). 
the litigation be transferred to the Federal Circuit, possibly because the Federal Circuit takes a relatively skeptical approach toward antitrust claims against patentees.

In addition, state court suits are pending in California (nine complaints), Florida (one), Kansas (one), New York (two), and Wisconsin (one). ${ }^{53}$ In the Wisconsin case, oral argument in state supreme court was scheduled for December 2006. ${ }^{54}$ In California and Kansas, litigation has been stayed pending resolution of the federal multidistrict litigation.

\section{K-Dur}

Potassium chloride in an extended-release form, sold by Schering-Plough under the brand name K-Dur, is a replacement for electrolytes lost from the body as a side effect of certain antihypertension drugs. U.S. sales of K-Dur in 1997, the year of settlement, totaled $\$ 190$ million. ${ }^{55}$

Schering and first-filer Upsher-Smith reached agreement in June $1997 .{ }^{56}$ Schering agreed to pay Upsher $\$ 60$ million. Upsher retained eligibility for the exclusivity period and the expectation of enjoying it upon entry, without fear of losing it by losing a patent suit.

From Schering's standpoint, the settlement neutralized the first-filer threat. The settlement also created a bottleneck. Schering also received licenses to five Upsher products, including Niacor, a sustained-release niacin product. This grant was described as the basis for Schering's cash payment. Schering also agreed to pay milestone royalty payments and a percentage royalty on sales, but the project came to nothing and these payments were never made. Upsher agreed to wait to enter until September 2001, later than the likely entry date if Upsher had won but earlier than the expiration of the relevant patent in September $2006 .{ }^{57}$ Upsher agreed to delay marketing not only the particular

\footnotetext{
${ }^{53}$ See Barr Pharmaceuticals 10-Q, supra note 2.

${ }^{54}$ The issue in Wisconsin supreme court, Meyers v. Bayer AG, No. 03AP2840, is the scope of Wisconsin's state antitrust law.

${ }^{55}$ According to Schering's internal estimate. See In re Schering-Plough Corp., No. 9297, 2003 WL 22989651, Part II.B.2 (F.T.C. Dec. 8, 2003) (reporting Schering estimate for 1997, made in June 1997).

56 Schering-Plough Corp. v. FTC, 402 F.3d 1056, 1059-60 (11th Cir. 2005).

${ }^{57}$ U.S. Patent No. 4,863,743.
} 
drug at issue, but also any other "microencapsulated" extended release potassium chloride product. ${ }^{58}$

Schering and later filer ESI Lederle ${ }^{59}$ reached agreement in January 1998. ${ }^{60}$ Schering agreed to pay ESI \$30 million, including a \$5 million noncontingent payment, \$10 million payment contingent on approval of ESI's generic product, and an additional $\$ 15$ million for certain licenses. Exclusivity was not an issue because as a later filer, ESI had no eligibility. Schering also received licenses from ESI pertaining to generic enalpril and buspirone, grants described as the basis for some (but not all) of Schering's cash payments. ESI agreed to wait to enter until January 2004, later than the likely entry date if ESI had won the suit but (as with Upsher) earlier than the expiration of the relevant patent in September 2006.

The K-Dur settlements attracted several challenges. ESI entered a consent decree with the FTC in 2002. ${ }^{61}$ Upsher chose to fight rather than settle with the FTC, and in 2003 the Commission concluded that defendants had violated antitrust law. ${ }^{62}$ In 2005, the Eleventh Circuit set aside the Commission decision and vacated its cease and desist order, ${ }^{63}$ and the Supreme court denied the FTC's petition for certiorari.

In addition, private antitrust suits have been consolidated as multidistrict litigation in a New Jersey district court. In 2004, the district court denied a motion to dismiss. ${ }^{64}$

\footnotetext{
${ }^{58}$ The relevant agreement term stated: “Upsher-Smith agrees that it will not market in the United States its KLOR CON ${ }^{\circledR}$ M20 potassium chloride product, or any other sustained release microencapsulated potassium chloride tablet, prior to September 1, 2001." See Schering, 2003 WL 22989651, Part IV.A. Upsher-Smith contested this interpretation of the clause. See UpsherSmith's Memorandum Addressing Complaint Counsel's Citations To The July 2002 FTC Study (filed Jan. 27, 2003) (link).

${ }^{59}$ ESI was owned by American Home Products Corp.

60 Schering, 402 F.3d at 1060-61. Schering and ESI reached agreement in January 1998. The final agreement was dated June 1998.

${ }^{61}$ FTC, Agreement Containing Consent Order, Apr. 2, 2002 (link).

62 See Schering, 2003 WL 22989651 (F.T.C. Dec. 8, 2003).

${ }^{63}$ Schering, 402 F.3d 1056.

${ }^{64}$ In re K-Dur Antitrust Litig., 338 F. Supp. 2d 517 (D.N.J. 2004).
} 


\section{Naprelan}

Naproxen sodium, sold by Elan under the brand name Naprelan, is a nonsteroidal drug used to manage pain, fever, and inflammation. U.S. sales of Naprelan in 1999, the year of the settlement, were $\$ 59$ million. ${ }^{65}$

Elan and first-filer SkyePharma reached agreement in May 1999, the details of which are difficult to discern from publicly available information. Elan granted SkyePharma the right to manufacture, possibly under Elan's NDA. So far as appears, SkyePharma retained entitlement to the exclusivity period, without fear of losing it by losing a patent suit. ${ }^{66}$

From Elan's perspective, the settlement removed a first-filer threat, and appears to create a bottleneck. Terms of entry are unclear.

The Naprelan settlement has attracted several challenges. Generic competitor Andrx filed an antitrust suit in 2001. ${ }^{67}$ In 2005, the Eleventh Circuit reversed the district court's dismissal, and the case remains pending on remand. A purchaser suit was filed in 2002 in the Eastern District of Pennsylvania, where it has remained on the suspense docket pending the outcome of the Florida case. ${ }^{68}$

\section{Procardia $\mathrm{XL}$}

Nifedipine in an extended-release form, sold by Pfizer under the brand name Procardia $\mathrm{XL}$, is a medication to reduce blood pressure and manage angina. U.S. sales of Procardia XL in 2000, the year of settlement, were \$311 million. ${ }^{69}$

Pfizer and first filer Mylan reached agreement in February 2000. Pfizer granted Mylan a license to sell a private-label version of Procardia XL supplied

65 Elan Corporation, PLC, 2000 Annual Report, at 21 (link) (reporting U.S. Naprelan revenue for 2000 and 1999). U.S. sales in 2000 were $\$ 42$ million.

${ }^{66}$ Andrx Pharm., Inc. v. Elan Corp., 421 F.3d 1227, 1231 (11th Cir. 2005).

${ }^{67}$ See SkyePharma PLC, Annual Report (Form 20-F) (June 24, 2006) (link) (reporting Andrx suit); Andrx, 421 F.3d 1227 (reversing district court's dismissal). The docket in the Southern District of Florida is No. 03-13605.

${ }^{68}$ See Action Alliance of Senior Citizens of Greater Phila. v. Elan Corp., No. 02-cv-2095 2003 WL 22358451 (E.D. Pa. Sept. 5, 2003).

${ }^{69}$ See Pfizer Inc., Consolidated Statement of Income, Jan. 24, 2001. U.S. sales in 1999 were $\$ 510$ million. 
by Pfizer. The license covered not only the 30 milligram dosage for which Mylan was the first filer, but also 60 and 90 milligram forms. It is not clear to what extent the private-label sales provided compensation to Mylan. Likely Mylan also had but declined the option, instead of private label sales, of a patent license agreement with a royalty on net sales. ${ }^{70}$ So far as appears, Mylan retained entitlement to the exclusivity period, without fear of losing it by losing a patent suit. From Pfizer's perspective, the settlement removed the first-filer threat and created a bottleneck.

The Procardia XL settlement attracted several challenges. Competitor generic firm Mylan filed an antitrust suit, complaining in part of the bottleneck. ${ }^{71}$ After the district court denied a motion to dismiss, Pfizer paid \$9 million to settle the case. A set of purchaser suits were consolidated in a West Virginia district court. ${ }^{72}$ After the district court denied class status in 2004, a settlement was reached dismissing some cases. ${ }^{73}$

\section{B. Incomplete settlements}

In the settlements in this section, the first-filing generic firm received no assurance of being able to enjoy the exclusivity period. The first two settlements, Cardizem CD and Hytrin, are interim settlements in which the innovator secured a delay in the first filing generic firm's entry pending resolution of the underlying patent dispute. (A second settlement involving Hytrin is not an interim agreement, but is included here for simplicity.) The third settlement, involving Prozac, resolved some but not all of the claims at issue.

70 The basis for this conclusion is that Procardia XL is likely the second "supply agreement" on p. 30 of the 2002 FTC study. As with Procardia XL, the supply agreement described by the FTC involved a drug with sales between $\$ 250$ million and $\$ 500$ million; was reached ten years, nine months before patent expiration (compare the February 2000 Procardia agreement and U.S. Patent No. 5,264,446, which expires in November 2010); took the form of an exclusive distribution deal; and covered strengths on which the generic firm had not filed an ANDA. If this analysis is correct, then, according to the FTC report, Mylan had but declined the option of choosing a patent license agreement with a royalty on net sales, instead of private label sales.

${ }^{71}$ Biovail Corp. v. Mylan Labs., Inc., No. 1:01CV66, 2002 U.S. Dist. LEXIS 6726 (N.D. W. Va. Mar. 22, 2002); Biovail Corporation Earnings Conference Call, July 29, 2003 (reporting \$9 million settlement).

72 Pfizer Inc., Quarterly Report (Form 10-Q) (Aug. 14, 2001) (noting Great Lakes Health Plan suit filed June 4, 2001, in E.D. Michigan); Pfizer, Quarterly Report (Form 10-Q) (May 15, 2002) (noting pendency of five suits in West Virginia district court).

${ }^{73}$ See Docket No. 01-cv-106 (N.D. W. Va.), Doc. 164 (filed Mar. 18, 2004) (denying class status); Doc. 169 (Apr. 2004) (settlement and dismissal as to Great Lakes Health Plan and Lotz). 


\section{Cardizem CD}

Diltiazem hydrochloride in a controlled-release form, sold by Hoescht Marion Roussel under the brand name Cardizem CD, is a widely prescribed medication for hypertension. ${ }^{74}$ U.S. sales of Cardizem CD in 1997, the year of settlement, were $\$ 692$ million. $^{75}$

Hoescht and first-filer Andrx ${ }^{76}$ reached agreement in September 1997. ${ }^{77}$ Hoescht agreed to pay Andrx $\$ 10$ million per quarter, plus an additional $\$ 60$ million per year if Hoescht lost the patent suit. Total payments equaled $\$ 89.83$ million. As for the exclusivity period, Andrx retained its exclusivity entitlement, and agreed not to give it up. But the settlement did not provide relief from the prospect of losing the patent suit, which continued.

From Hoescht's standpoint, the "interim" agreement removed the risk that Andrx would launch immediately upon receiving FDA approval, though it did not resolve the patent suit. The settlement also created a bottleneck, since later ANDA-IV filers could not receive FDA approval until 180 days after entry of a first filer with exclusivity eligibility. Andrx agreed to delay marketing not only the particular drug at issue, but also other noninfringing products.

The Cardizem CD settlement attracted several challenges. An FTC consent decree was entered in 2001. ${ }^{78}$ Generic competitor Biovail filed an antitrust suit, and after the D.C. Circuit denied dismissal in 2001, the parties settled in 2002. ${ }^{79}$ Litigation by purchasers yielded several large settlements$\$ 110$ million for direct purchasers and $\$ 80$ million for indirect purchasers and state attorneys general-and in 2003, the Sixth Circuit condemned the settlement as a violation of antitrust law. ${ }^{80}$

${ }^{74}$ Andrx Pharm., Inc. v. Biovail Corp. Int'l, 256 F.3d 799, 803 (D.C. Cir. 2001).

75 1999: A Pivotal Year for Generics Pricing, DRUG STORE NeWS, Feb. 15, 1999 (reporting U.S. sales of $\$ 691.7$ million).

76 Andrx is now part of Watson Pharmaceuticals.

77 See In re Cardizem CD Antitrust Litig., 332 F.3d 896 (6th Cir. 2003).

${ }^{78}$ In re Hoechst Marion Roussel, Inc., No. 9293, 2001 WL 333643 (F.T.C. Apr. 2, 2001).

${ }^{79}$ Andrx, 256 F.3d 799; Andrx Corp., Annual Report (Form 10-K), at 5 (Mar. 31, 2003) (reporting July 2002 settlement with Biovail).

${ }^{80}$ In re Cardizem CD Antitrust Litig., 332 F.3d 896 (6th Cir. 2003); Andrx Corp., Current Report (Form 8-K) (Oct. 31, 2002), Exh. 99.1, “Andrx Corporation Reports Financial Results for the Third Quarter of 2002." (direct purchaser settlement); Press Release, Office of the Att'y Gen., Attorney General Lockyer Announces $\$ 80$ Million Settlement of Antitrust Case Against Drug Makers for Limiting Access to Generic Heart Medication (Jan. 27, 2003) (link) (indirect purchaser 


\section{Hytrin}

Terazozin hydrochloride, sold by Abbott under the brand name Hytrin, is an antihypertension drug used to treat high blood pressure. U.S. sales of Hytrin in 1998, the year of settlement, were $\$ 542$ million. ${ }^{81}$

To understand the settlement that resulted, it is necessary to review briefly the underlying patent suit. Two forms of terazosin hydrochloride, dihydrate and "Form IV" anhydrous, and two patents, are particularly relevant. Dihydrate was the form used by Abbott in Hytrin, protected by a patent expiring in February 2000.82 Generic firm Geneva proposed to make a bioequivalent Form IV product, which would not infringe the dihydrate patent but would infringe a patent on Form IV not scheduled to expire until October $2014 .{ }^{83}$ Geneva acknowledged infringement of the Form IV patent but argued, ultimately successfully, that this patent was invalid.

Abbott and first-filer Geneva reached agreement in April 1998. ${ }^{84}$ Abbott agreed to make payments of up to $\$ 101$ million. The formula was to pay $\$ 4.5$ million per month until a district court judgment. If the generic firm won in district court, $\$ 4.5$ million per month would go into escrow during appeal, payable if Geneva won. The agreement was scheduled to end at the earliest of the invalidation of the Form IV patent, another generic firm's entry, and February 17, 2000. ${ }^{85}$ The latter date was the expiration of the dihydrate patent, not directly relevant to the litigation. ${ }^{86}$ As for the 180-day exclusivity period, Geneva

settlement). According to the release, $\$ 21$ million was allocated to individual consumers, $\$ 4.5$ million to state agencies, $\$ 15.6$ million to plaintiffs' counsel, $\$ 2.5$ million to state attorneysgeneral, and an additional sum to health plans.

${ }^{81}$ See In re Abbott Labs. \& Geneva Pharm., Inc., No. C-3945, 2000 WL 681848 (F.T.C. May $22,2000)$.

82 U.S. Patent No. 4,215,532.

${ }^{83}$ U.S. Patent No. 5,504,207. The description in text is of claim 4. The patent also claims making terazosin $\mathrm{HCl}$ dihydrate using Form IV as an intermediary.

${ }^{84}$ See In re Terazosin Hydrochloride Antitrust Litigation, 164 F. Supp. 2d 1340 (S.D. Fla. 2000); Valley Drug Co. v. Geneva Pharm., Inc., 344 F.3d 1294 (11th Cir. 2003).

$85 \$ 4.5$ million per month, applied to nine months of 1998 , twelve months of 1999 , and 1.61 months of 2000 .

${ }^{86}$ The inclusion of the '532 dihydrate patent's expiration as a settlement term is initially puzzling, since this patent was not directly relevant to the ongoing dispute. A possible explanation is that Abbott understood that the last possible moment for exclusive Hytrin sales was February 2000 - that after the '207 patent expired, generic firms would be free to sell a dihydrate version. The parties may have concluded that an expiration date for the agreement that extended beyond that point would raise an antitrust risk. 
retained its exclusivity entitlement, and agreed not to give it up. But the settlement apparently did not provide relief from the prospect of losing the patent suit, which continued.

From Abbott's standpoint, the "interim" agreement removed the risk that Geneva would launch immediately upon receiving FDA approval-and even if Geneva won in the district court, during the pendency of appeal-though it did not resolve the patent suit. The settlement also created a bottleneck. Geneva agreed to delay marketing not only the particular drug at issue, but all terazosin hydrochloride products, even if noninfringing.

Abbott and later filer Zenith ${ }^{87}$ reached agreement in March 1998. ${ }^{88}$ Abbott agreed to pay Zenith up to slightly more than $\$ 45$ million. The formula was $\$ 3$ million up front, $\$ 3$ million in the second quarter of 1998, $\$ 6$ million per quarter for the last two quarters of 1999 and throughout 2000, and slightly more than \$3 million for the prorated period between January 1 and February 17, 2000. (As with the Abbot-Geneva agreement, the latest end to the agreement was the expiration of the dihydrate patent.) If a generic firm entered, the payments would cease, except for $\$ 3$ million per quarter during another firm's exclusivity period. Exclusivity was not an issue because as a later filer, Zenith had no eligibility. Unlike the Geneva agreement, this was a final agreement. Zenith agreed to enter no earlier than in February 2000, and to delay marketing of all terazosin hydrochloride products, even if noninfringing.

The Hytrin settlements have attracted several challenges. The FTC reached a consent decree as to the Abbott-Geneva agreement in 2000, apparently having taken no action with respect to the Zenith agreement. ${ }^{89}$ A variety of antitrust suits were consolidated in multidistrict litigation. ${ }^{90}$ Zenith reached a settlement. In 2003, the Eleventh Circuit ruled that the district court's conclusion of per se illegality as to the Geneva agreement had been "premature." The plaintiffs subsequently narrowed their case to the "appellate stay" period of the

\footnotetext{
${ }^{87}$ Zenith became part of Ivax, which is now part of Teva.

88 See Abbott-Zenith Hytrin Agreement, supra note 22; Terazosin, 164 F. Supp. 2d 1340; Valley Drug, 344 F.3d at 1300 (noting expiration in March 1, 2000).

89 In re Abbott Labs. \& Geneva Pharm., Inc., No. C-3945, 2000 WL 681848 (F.T.C. May 22, 2000) (Geneva); In re Abbott Labs. \& Geneva Pharm., Inc., No. C-3946, 2000 WL 681849 (F.T.C. May 22, 2000) (same); See Ivax Corp., Annual Report (Form 10-K) (Mar. 30, 2000) (link) (noting FTC complaint against Abbott and Geneva but none against Zenith).

${ }^{90}$ Valley Drug, 344 F.3d 1294; In re Terazosin Hydrochloride Antitrust Litigation, 352 F. Supp. 2d 1279, 1286 (S.D. Fla. 2005). The docket number in the Southern District of Florida is 99MDL-1317.
} 
settlement, which prohibited entry during the pendency of the patent appealthat is, after the district court's invalidation of the patent in September 1998, and before the Federal Circuit's affirmance in August 1999. On remand, the district court concluded that the appellate stay component violated antitrust law, and entered summary judgment for defendants. Most plaintiffs in the MDL litigation settled..$^{91}$

One case that did not settle, brought by Kaiser Foundation Health Plan, returned to the Central District of California upon its release from MDL. In 2006, after a trial, the jury returned a verdict for defendants. Appeal in the Ninth Circuit is pending. ${ }^{92}$

\section{Prozac}

Fluoxetine hydrochloride, sold by Eli Lilly and Company under the brand name Prozac, is an antidepressant. U.S. sales of Prozac in 1999, the year of the settlement, were $\$ 2.09$ billion. ${ }^{93}$

Two patents are particularly relevant to the subsequent settlement: the compound patent, which expired in August 2001, ${ }^{94}$ and a follow-on patent on Prozac's administration to prohibit serotonin uptake, scheduled for expiration in June 2004. ${ }^{95}$ Generic firms Barr and Geneva were each first to file on different strengths. ${ }^{96}$ Lilly sued, and the district court ruled in favor of Lilly on two invalidity issues, obviousness-type double patenting and best mode. That left several other claims to resolve at trial.

In January 1999, on the eve of trial, Lilly reached agreement with Barr and Geneva as to the remaining claims. ${ }^{97}$ Lilly paid Barr and Geneva $\$ 4$ million in

91 The amount of settlement was reportedly $\$ 30,700,000$. See Cafferty, supra, at 4 .

${ }_{92}$ See Jury Verdict, Kaiser Found. v. Abbott Labs., No. 2:02cv2443 (C.D. Cal. Apr. 4, 2006). The Ninth Circuit appeal is docketed as Nos. 06-55687 and 06-55748. See, e.g., Brief of Appellant, Abbott Labs. (Nov. 14, 2006), 2006 WL 3889913 (appellant's principal brief).

${ }^{93}$ Eli Lilly and Co., Annual Report (Form 10-K) (Mar. 30, 2000) (link).

${ }_{94}^{4}$ U.S. Patent No. 4,314,081. The August 2001 figure in text reflects pediatric extension. The focus was claim 5 .

${ }_{95}$ U.S. Patent No. 4,626,549. The June 2004 figure in text reflects pediatric extension. The focus here was claim 7.

${ }^{96}$ Barr on $20 \mathrm{mg}$, Geneva, part of Novartis, on $10 \mathrm{mg}$. See Letter from FDA to Geneva Pharmaceuticals re: ANDA 75-049 (Aug. 2, 2001) (link).

${ }^{97}$ See David J. Morrow, Lilly and 3 Rivals to Settle Prozac Suit for \$4 Million, N.Y. TIMES, Jan. 26, 1999, at C2; Eli Lilly and Co., Quarterly Report (Form 10-Q) (Nov. 14, 2000) (link); Prozac, Eli 
total. By giving up the remaining claims, the generic firms appealed more rapidly the adverse summary judgment ruling. Lilly, for its part, avoided a trial on the claims, and avoided the prospect of a launch at risk upon the expiration of the automatic stay.

In May 2001, the Federal Circuit ruled the follow-on patent invalid. ${ }^{8}$ Barr and Geneva entered in August 2001, upon expiration of the compound patent, each with exclusivity for different strengths.

\section{Second-wave settlements}

This Part describes settlements in ten drugs reached since March 2004. For settlements involving seven drugs, the 180-day generic exclusivity period is potentially relevant. For three other drugs, exclusivity is not an issue because no generic filer has potential eligibility.

\section{A. Settlements implicating exclusivity}

\section{Niaspan}

Niacin in an extended-release form, sold by $\operatorname{Kos}^{99}$ under the brand name Niaspan, is a medicine to manage cholesterol, primarily by raising HDL ("good") cholesterol. U.S. sales of Niaspan in 2005, the year of settlement, were $\$ 380$ million. ${ }^{100}$

To understand the settlement that resulted, it is necessary to review briefly the underlying patent suit. ${ }^{101}$ Two patents expiring in 2013 and 2017,

Lilly and Co., Med AD News, Mar. 1, 1999. See also Paying Off Generics to Prevent Competition with Brand Name Drugs: Should it Be Prohibited?: Hearing Before the S. Comm. on the Judiciary, 110th Cong. (2007) (statement of Bruce Downey, Chairman and CEO of Barr Pharmaceuticals) (discussing the settlement). (The prepared testimony (link) does not discuss the payment.)

${ }^{98}$ A panel of the Federal Circuit initially reached this conclusion in August 2000, but that ruling was vacated and replaced with a second opinion reaching the same conclusion. See Eli Lilly \& Co. v. Barr Labs., 222 F.3d 973 (Fed. Cir. 2000); 251 F.3d 955 (Fed. Cir. 2001).

${ }^{99}$ Kos is now part of Abbott.

100 See www.drugs.com/top200.html (U.S. sales in 2005); see also Kos Pharmaceuticals, Annual Report (Form 10-K) (Mar. 16, 2006) (worldwide sales in 2005 of \$435 million); Q4 Abbott Laboratories Earnings Conference Call, Jan. 24, 2007 (worldwide sales in 2006 of about \$500 million).

101 See Kos Pharmaceuticals, Quarterly Report (Form 10-Q) (Nov. 9, 2004) (link). 
respectively, cover the product. ${ }^{102}$ Barr filed an ANDA-IV with respect to these patents, and Kos sued. As new Kos patents issued beyond these two, Barr added new paragraph IV certifications to its ANDA, and Kos filed additional patent infringement suits in New York district court. The automatic stay was scheduled for expiration on March 30, 2005, whereupon Barr would be free to launch at risk. The trial was expected to occur in early 2006.

The challenged patents also protected Advicor, a second product marketed by Kos. Advicor is a tablet containing a mixture of Niaspan and lovastatin, a drug that lowers LDL ("bad") cholesterol. Worldwide sales of Advicor in 2005 were $\$ 116$ million. ${ }^{103}$

Kos and first-filer Barr reached agreement in April 2005. ${ }^{104}$ Kos agreed to pay Barr an undisclosed amount, described as compensation for helping to promote the drug. Kos also agreed to make payments initially and quarterly, described as compensation for manufacturing services. So far as appears, Barr retained entitlement to the exclusivity period, without fear of losing it by losing a patent suit.

From Kos's standpoint, the settlement neutralized the first filer and created a bottleneck. Under the agreement, Barr is scheduled to launch generic versions of Niaspan and Advicor, including line extensions, in September 2013, approximately four years earlier than the latest-expiring patent. Barr also agreed to co-promote Niaspan and Advicor (and line extensions) to obstetricians and gynecologists, to "stand ready" to produce Niaspan and Advicor for Kos, and (in exchange for additional payments) to actually produce the product if Kos wishes.

\section{Effexor XR}

Venlafaxine hydrochloride in an extended-release form, sold by Wyeth under the brand name Effexor XR, is an antidepressant. U.S. sales of 2005 of both Effexor XR and Effexor were $\$ 2.275$ billion. ${ }^{105}$

\footnotetext{
102 U.S. Patent No. 6,080,428; U.S. Patent No. 6,129,930.

${ }_{103}$ See Abbott Laboratories: Kos Pharmaceuticals a Wise Buy, PHARMACEUTICAL BUSINESS RevieW, Nov. 8, 2006 (reporting sales of $\$ 116$ million).

${ }^{104}$ Kos and Barr Announce Definitive Co-Promotion, Manufacturing and Settlement Agreements (Apr. 13, 2005) (link).

105 The U.S. sales figure is derived from net revenue figures reported by Wyeth: $\$ 576,131$ in Q1 2005, \$579,881 in Q2; \$568,865 in Q3, and \$550,244 in Q4. See, e.g., Wyeth Q1 2006 Net
} 
Wyeth and first filer Teva reached agreement in December 2005.106 Wyeth granted Teva an exclusive license to sell Effexor starting in June 2006. This is a potentially lucrative source of compensation for a generic firm, depending upon the price of the license. (Teva must pay royalties, but their size is not disclosed.) Teva retained entitlement to the exclusivity period, without fear of losing it by losing a patent suit.

From Wyeth's standpoint, the settlement neutralized the first filer and created a bottleneck. Teva agreed to enter as to Effexor XR in July 2010. That date is later than entry if a generic firm won a patent challenge, but earlier than the expiration of Wyeth patents on extended-release formulations of venlafaxine $\mathrm{HCl}$. (Teva did not challenge the compound patent, which expires in June 2008.)

\section{Provigil}

Modafinil, sold by Cephalon under the brand name Provigil, is a stimulant, "the first in a new class of wake-promoting agents." 107 U.S. sales in 2005 and 2006, during which the settlements were reached, were $\$ 476$ million and $\$ 685$ million, respectively. ${ }^{108}$

Cephalon reached agreement with four first filers in late 2005 and early 2006: Teva, Ranbaxy, Mylan, and Barr. Cephalon agreed to pay up to $\$ 136$ million to Barr, Ranbaxy, and Teva, described as compensation for modafinilrelated intellectual property. This compensation takes the form of upfront fees,

Revenue Report (link) (reporting Q1 2005). See also Wyeth Pharmaceuticals, Wyeth Reports Earnings Results for the 2005 Fourth Quarter and Full Year, Jan. 31, 2006 (link) (reporting worldwide sales for both products of $\$ 3.5$ billion).

${ }^{106}$ Wyeth Pharmaceuticals, Current Report (Form 8-K) (Jan. 13, 2006) (describing terms). Teva retains entitlement to the 180-day exclusivity period upon its entry in July 2010. See Event Brief of Q3 2005 Teva Pharmaceutical Earnings Conference Call, Nov. 8, 2005 (Teva taking view that it retains eligibility for the exclusivity period).

Agreement on principal terms was announced in October 2005. Agreement was actually reached in December 2005, and became "final" in January 2006. Press Release, Teva Pharmaceutical Industries, Ltd., Teva and Wyeth Announce Settlement of Effexor XR Litigation (Oct. 18, 2005) (link) (describing principal terms); Wyeth 2005 Financial Report (link) (noting date of actual agreement).

${ }^{107}$ Cephalon, What is Provigil? (link).

108 Cephalon Reports Outstanding Financial Results for 2005, PR Newswire, Feb. 14, 2006 (reporting 2005 sales of \$475,557); Milena Izmirlieva, Cephalon's 2006 Revenues Jump 46\% on Strong Provigil Sales, GLOBAL Insight DAILy ANALYSIS, Feb. 13, 2007 (reporting 2006 results). 
royalties, and milestone payments. ${ }^{109}$ Cephalon also agreed to pay $\$ 82.6$ million for materials, beginning in 2006 and lasting for six years, to three unnamed "modafinil suppliers." The announcements of agreements with Teva and Ranbaxy explicitly mention supply agreements; likely they are two of the three suppliers. The agreement with Barr includes purchase of inventory, but it is unclear whether this is Cephalon's third supply agreement. The descriptions below assume that Teva, Ranbaxy, and Barr are the three suppliers. If the three suppliers are correctly identified, then Barr, Ranbaxy, and Teva share in payments of up to $\$ 218.6$ million. In addition to these three agreements, Cephalon settled with Mylan, as described below. After these settlements, Cephalon's CEO stated that thanks to the agreements, "we were able to get six more years of patent protection. That's $\$ 4$ billion in sales that no one had expected." 110

The four settlements share certain features. The generic firm receives cash, described as consideration for value other than delay. The generic firm retains shared entitlement to the exclusivity period, without fear of losing it by losing a patent suit. From Cephalon's standpoint, the settlement neutralizes the first filer and creates a bottleneck (as to later firms, not the other first filers). The generic firm agrees to enter as of October 2011, or six months later if Cephalon secures a six-month pediatric extension. That date is later than entry if a generic firm won a patent challenge, but earlier than the October 2014 expiration of the patent at issue. ${ }^{111}$

Cephalon reached agreement with Teva in December 2005. ${ }^{112}$ In that settlement, the cash is described as consideration for modafinil-related intellectual property and "certain arrangements ... related to Teva's manufacture and supply" of modafinil to Cephalon. Cephalon also reached agreement with Ranbaxy in December 2005. ${ }^{113}$ The visible terms are identical, with the omission of a manufacturing component; intellectual property and

${ }^{109}$ Cephalon, Quarterly Report (Form 10-Q) (May 10, 2006) (link); Cephalon, Annual Report (Form 10-K) (Mar. 13, 2006).

${ }^{110}$ John George, Hurdles Ahead for Cephalon, PhiladelPhia Business Journal, Mar. 17, 2006.

111 U.S. Patent No. RE37,516 (with pediatric extension, April 2015).

112 Teva Announces Agreement with Cephalon Regarding Settlement of PROVIGIL

Patent Litigation; Parties Also Agree to Business Arrangements Related to Modafinil, Business Wire, Dec. 9, 2005.

${ }^{113}$ Cephalon, Inc. Announces Agreement with Ranbaxy Laboratories Limited Regarding Settlement of PROVIGIL(R) Patent Litigation, Dec. 22, 2005 (link). 
supply "certain arrangements ... related to Ranbaxy's supply" are described as consideration for payment.

Cephalon reached agreement with Mylan in January 2006. ${ }^{114}$ The agreement apparently includes no intellectual property licenses or supply agreement. ${ }^{115}$ Instead, Mylan will receive payments (distinct from the payments described above) as part of certain product development collaboration agreements. ${ }^{116}$

Cephalon reached agreement with Barr in February 2006. In that settlement, the cash is described as consideration for intellectual property licenses and inventory. The agreement also addressed litigation between Cephalon and Barr over Actiq, an important antipain medication sold by Cephalon. The overall agreement expanded Barr's existing license to sell generic Actiq under very specific circumstances. It may also have granted Barr a fraction of Cephalon sales on an unrelated next-generation pain medication of Cephalon's. See Part IV.A.4 infra.

Cephalon also reached agreement with a later filer, Carlsbad, in August 2006. That agreement provided for entry in April 2012. Other terms have not been disclosed.

The Provigil settlements have attracted several challenges. The FTC requested information about the settlements in March 2006 and requested additional information in July 2006. ${ }^{117}$ A purchaser suit was filed in Pennsylvania district court in April 2006. ${ }^{118}$ Competitor Apotex also filed an

${ }^{114}$ Cephalon, Inc. Announces Agreement with Mylan Pharmaceuticals Inc. Regarding Settlement of PROVIGIL(R) Patent Litigation, Jan. 10, 2006 (link) (making no mention of intellectual property or supply agreements).

${ }^{115}$ Cephalon's announced list of modafinil IP providers includes Teva, Ranbaxy, and Barr, but omits Mylan, and the announcements of the Mylan agreement omitted mention of intellectual property or supply.

116 Cephalon Inc., Current Report (Form 8-K), at 2 (Jan. 9, 2006) (noting that parties had "entered into two product development collaboration agreements under which the companies will explore utilizing Mylan Technologies Inc.'s transdermal technology to address pain and certain central nervous system disorders. Under the arrangements, Cephalon will have an option to develop and commercialize the products in exchange for payment of milestones and ongoing royalties based on net sales of the products.").

117 See Kristina Henderson, Cephalon: FTC Seeks Info on Provigil Agreement, DOW JONES CORP. FILINGS AlERT, July 13, 2006; Cephalon Inc., Current Report (Form 8-K) (July 13, 2006) (link) (reporting FTC's request for additional information).

118 In re Modafinil Antitrust Litigation, No. 06-cv-01797 (E.D. Pa. Apr. 27, 2006). 
antitrust suit, alleging that the bottleneck has blocked it from approval of its ANDA.

\section{Actiq}

Oral transmucosal fentanyl citrate, sold by Cephalon under the brand name Actiq, is a pain reliever delivered as a "lollipop," a lozenge attached to a handle. U.S. sales of Actiq in 2006, the year of settlement, were $\$ 545$ million. ${ }^{119}$

To understand the resulting settlement, it is helpful to review the underlying patent suit. In August 2004, Cephalon granted Barr a license to market generic Actiq, starting in September 2006. This was due to the FTC's insistence that Cephalon grant a license as a condition for permitting its merger with Cima Labs, a company making a next-generation pain reliever. ${ }^{120}$ Under the license, Barr's September 2006 entry would be accelerated if Cephalon received earlier approval of Fentora, its next-generation tablet antipain medication. ${ }^{121}$ If Cephalon received a pediatric extension, entry would be pushed back to February 2007.

Notwithstanding the license, Barr filed an ANDA-IV for Actiq in October 2004, and Cephalon received notice in December 2004. Cephalon filed a patent suit in January 2005, triggering the 30-month stay. ${ }^{122}$ The patent at issue, however, was set to expire in September $2006,{ }^{123}$ so the practical effect of the patent suit is unclear. At the time of the suit, Cephalon declared that it expected no change in the likely date of market entry. ${ }^{124}$ The patent suit was unlikely to be resolved before patent expiration, and without a ruling the automatic stay would remain pending until then. It is possible that Barr thought it might win quickly,

119 Press Release, Cephalon Inc., Cephalon Reports Record Sales and Earnings for 2006 (Feb. 12, 2007) (link) (reporting U.S. sales, in thousands, of $\$ 475,557$ for 2005 and $\$ 544,886$ for 2006).

120 See Barr Granted Rights to Generic of Cephalon's ACTIQ(R) Cancer Pain Treatments License and Supply Agreement Results from Cephalon, Inc. and CIMA LABS INC. Merger, PR Newswire, Aug. 10, 2004.

${ }^{121}$ In some filings, Fentora is referred to as OraVescent.

122 See Barr Pharmaceuticals Inc., Barr Launches Generic ACTIQ Cancer Pain Management Product, Sept. 27, 2006 (link) (noting October 2004 ANDA-IV filing, December 2004 notification of Cephalon, and January 2005 suit).

${ }^{123}$ U.S. Patent No. 4,863,737. Cephalon Inc. v. Barr Laboratories, No. 05-29 (D. Del.). Document \#37 is plaintiffs' opening brief on claim construction for Patent No. 4,863,737.

${ }_{124}$ Press Release, Cephalon Inc., Anticipated Generic ACTIQ Filing Occurs; Cephalon Expects No Change in Barr's Likely Date of Market Entry (Dec. 8, 2004) (link). 
and secure early entry protected by exclusivity. A second possibility is that settlement of this suit provided a means for additional compensation from Cephalon to Barr in connection with the simultaneous settlement of Provigil litigation.

Cephalon and first filer Barr reached agreement in February 2006, in conjunction with settlement of the Provigil litigation. Barr secured a license to sell two months earlier, but only under particular circumstances. The change applied only if Cephalon secured pediatric exclusivity for Actiq but did not launch Fentora early. In that case, Barr would be entitled to a license in December 2006 rather than February 2007. This term was never triggered. Instead, Barr began to sell generic Actiq in September 2006 upon the FDA's early approval of Fentora. ${ }^{125}$

It is possible, however, that Barr receives a portion of Fentora sales. And if so, the Actiq litigation and settlement served to provide an additional means for Cephalon to make a payment to Barr. Recall the discussion in Part II.A.4, describing a particular settlement in which the brand-name firm paid royalties on a different version of the drug. The Actiq agreement fits this discussion in important respects, provided that "capsule" is understood to be a reference to the lozenge delivery mechanism of Actiq. As in the FTC account, Cephalon granted Barr a license to an authorized generic of the lozenge form; this lozenge form was the subject of the relevant litigation; Cephalon acquired a new tablet form of the product, that is, Fentora; and later, the parties dismissed the litigation involving the lozenge form. If the match is correct, then it can be inferred from the FTC report that one term of the settlement was for Cephalon to pay Barr a royalty on sales of Fentora.

The Actiq settlement has attracted an FTC investigation. ${ }^{126}$

\section{Plavix}

Clopidogrel bisulfate, sold by Bristol-Myers Squibb ${ }^{127}$ under the brand name Plavix, is an anti-platelet drug used to prevent blood clots and the world's

\footnotetext{
${ }^{125}$ Jonathan Goodall, Barr Challenges Savient's Oxandrin Patents, Launches Generic Actiq, GLOBAL INSIGHT DAily ANALYSIS, Sept. 28, 2006.

${ }^{126}$ See Cephalon filing (noting FTC request for "certain information in connection with its review of this settlement").

${ }^{127}$ Sanofi-Aventis owns the '266 patent, and jointly markets Plavix with Bristol in the United States.
} 
second bestselling medicine. U.S. sales in 2005, the year prior to the attempted settlement, were $\$ 3.2$ billion. ${ }^{128}$

Any agreement between Bristol and first-filer Apotex required approval by the FTC and state attorneys general, under the terms of an earlier consent decree meant to address prior alleged anticompetitive activity by Bristol. Regulators rejected an initial agreement in March 2006, which led to a May 2006 revised agreement. The May 2006 version was rejected too, and in August 2006, Apotex launched at risk. In three weeks, Apotex flooded the market with more than a billion dollars of generic Plavix before a district judge halted further sales pending resolution of the patent suit. ${ }^{129}$

Upon the launch, certain provisions protecting Apotex took effect. Bristol had accepted a contractual delay in its ability to seek a preliminary injunction if Apotex launched at risk. Bristol also agreed that if Apotex launched a generic product and was later found liable for patent infringement, its damages would be capped at a reduced level.

Other provisions of the agreement never took effect. ${ }^{130}$ For example, Bristol had agreed to pay Apotex $\$ 40$ million, described as compensation for inventory. Apotex retained eligibility for the exclusivity period and the expectation of enjoying it upon entry, without fear of losing it by losing a patent suit. Two other sources of compensation were present in the March agreement, and Apotex alleges (and Bristol denies) that they were unwritten terms of the May revision: a commitment not to launch an authorized generic during Apotex's exclusivity period, and a breakup fee to Apotex if regulators rejected the deal. The breakup fee increased with the degree of delay in the regulators' response.

From Bristol's perspective, the settlement neutralized the first filer and created a bottleneck. Under the May agreement, entry by Apotex was permitted as of April 2011, or June 2011 if Bristol secured a pediatric extension. (Under the

\footnotetext{
128 See Val Brickates Kennedy, Bristol-Myers CFO: Preparing for the Plavix Plunge, MARKETWATCH, Feb. 14, 2007 (link).

129 See Bristol-Myers Squibb, Annual Report (Form 10-K), at 31 (Feb. 26, 2007) (link) (estimating negative effects from Apotex inventory of $\$ 1.2$ to $\$ 1.4$ billion in 2006).

130 See Plavix Agreement, supra note 22; John Carreyrou \& Joann S. Lublin, Emergency Room: How Bristol-Myers Fumbled Defense of \$4 Billion Drug, WALL ST. J., Sept. 2, 2006; Bethany McLean, Party Crasher, ForTunE, Feb. 5, 2007 (link); Sanofi-Synthelabo v. Apotex, Inc., 470 F.3d 1368 (Fed. Cir. 2006) (noting November 2011 expiration of '265 patent).
} 
March agreement, entry was permitted as of March 2011, or September 2011 if BMS secured a six-month pediatric extension.) That date was later than entry if Apotex won its patent challenge, but earlier than the November 2011 expiration of the patent at issue. ${ }^{131}$ Apotex also agreed to transfer inventory to Bristol, described as consideration for Bristol's cash payment.

The failed Plavix settlement has attracted several challenges. In 2006, the Department of Justice opened a criminal inquiry into whether Bristol had misrepresented the content of its deal to regulators by omitting mention of the a breakup fee and a no-authorized-generic covenant. Also in 2006, purchasers filed an antitrust suit in an Ohio district court. ${ }^{132}$

\section{Adderall XR}

Adderall $\mathrm{XR}$ is the brand name for a mixture of amphetamine salts in an extended release form, sold by Shire and prescribed to treat attention deficit hyperactivity disorder. Worldwide sales of Adderall XR in 2006, the year of settlement, were $\$ 864$ million. ${ }^{133}$

Shire and first-filer Barr reached agreement in August 2006. ${ }^{134}$ Shire agreed to pay Barr a net amount of up to $\$ 102$ million. That is, Shire agreed to pay a Barr subsidiary up to $\$ 165$ million $-\$ 25$ million immediately and up to $\$ 140$ million over eight years - described as compensation for product development. And Barr agreed to pay Shire $\$ 63$ million, described as compensation for transferring Shire's rights to Adderall IR (immediate-release) tablets.

Barr retained exclusivity eligibility without fear of losing it by losing a patent suit. Moreover, during the 180-day exclusivity period, Shire agreed not to compete with Barr through an authorized generic. (Barr will pay Shire a royalty during the exclusivity period; thereafter, the license is nonexclusive and royalty-

131 U.S. Patent No. 4,847,265.

${ }_{132}$ See Amended Complaint and Demand for Jury Trial, Kroger Co. v. Sanofi-Aventis, No. 06-00163 (S.D. Ohio July 31, 2006), 2006 WL 2503664.

${ }^{133}$ Shire PLC - Final Results, PR Newswire UK Disclose, Feb. 20, 2007 (2006 sales); see also Shire 2005 Annual Report (reporting worldwide sales of $\$ 731$ million in 2005).

${ }_{134}$ See Barr Pharmaceuticals, Barr and Shire Sign Three Agreements (Aug. 14, 2006) (link); Barr Pharmaceuticals 10-Q, supra note 2 (discussing agreements); Adderall XR Agreement, supra note 22 (setting out, respectively, settlement, product development, and Adderall IR agreements, with some redactions). 
free. $)^{135}$ Barr also received the rights to Shire's Adderall IR product and to purchase a supply of Adderall IR from Shire. It is unclear whether the deal price of $\$ 63$ million or transfer price for supply permits significant compensation from Shire to Barr.

From Shire's standpoint, the settlement removed the first filer threat and created a bottleneck. Barr agreed to enter as of April 2009, a date later than if Barr had launched at risk or after winning a patent challenge, and earlier than the expiration of the last-to-expire patent. ${ }^{136}$ Shire also received product development pertaining to six proprietary Barr women's health products, described as consideration for the $\$ 165$ million payment. As to these products, there is also provision for Barr to supply product to Shire, in exchange for additional compensation.

Shire and later filer Impax reached agreement in January 2006. ${ }^{137}$ Impax received cash, described as compensation for promotion of another drug. Exclusivity was not an issue because as a later filer, Impax had no eligibility. Impax agreed to enter in January 2010. Shire also received promotion for Carbatrol, a Shire epilepsy drug, described as consideration for the cash payment.

The Shire-Barr agreement has attracted an FTC investigation, opened in October 2006. ${ }^{138}$

135 Adderall XR Agreement, supra note 22, at Exh. 10.1, License Agreement (appended as "Exhibit A"), clause 3.7 ("Shire has not granted and will not grant a license ... [or] other arrangement that allows any Third Party to market a Generic Equivalent before (i) the License Effective Date or (ii) the expiration of 180 days following Barr's launch of a Generic Product, [redacted]"); Event Brief of Q4 2006 Barr Pharmaceuticals, Inc. Earnings Conference Call, Aug. 15, 2006 (noting the no-authorized-generic provision).

136 The patents at issue were 6,322,819 (expiring Oct. 2018), 6,605,300 (expiring Oct. 2018), and 6,913,768 (issued July 5, 2005, expiring Jan. 2023). See Shire, Annual Report (Form 10-K), at 20 (Mar. 1, 2007) (link). The ' 819 and '300 patents are listed in the Orange Book, but not the '768 patent. The press release described entry as nine years earlier than the last-to-expire patents in the Orange Book.

137 Shire, Impax Settle Adderall XR Lawsuits; Barr Still in Talks, GENERIC LINE, Jan. 25, 2006.

138 See Barr Pharm: FTC Probing Shire Settlement Over Adderall XR, DOW JONES CORPORATE Filings ALERT, Nov. 10, 2006; Barr Pharmaceuticals 10-Q, supra note 2 (reporting Oct. 3, 2006 notification by FTC of investigation). 


\section{AndroGel}

Testosterone gel 1\%, sold by Solvay under the brand name AndroGel, is a male hormone used in hormone replacement therapy. U.S. sales of AndroGel in 2005 , the year before settlement, were about $\$ 330$ million. ${ }^{139}$

Solvay ${ }^{140}$ and first-filer Watson reached agreement in September 2006. ${ }^{141}$ Solvay agreed to pay Watson an undisclosed amount, described as compensation for promotion. Watson forfeited its 180-day entitlement, but may expect to have 180 days of duopoly nevertheless: its licensed entry date is 180 days earlier than generic firm Par's entry date. ${ }^{142}$

From Solvay's standpoint, the settlement neutralizes the first filer, though it does not create a bottleneck thanks to the forfeiture. Aside from agreeing to enter in August 2015, Watson agreed to promote AndroGel to urologists.

Solvay and later filer $\operatorname{Par}^{143}$ reached agreement in September 2006. ${ }^{144}$ Solvay agreed to pay Par $\$ 60$ million $-\$ 10$ million per year for six years, paid quarterly-described as compensation for co-promotion. Solvay also entered a "backup" manufacturing deal, which may be a source of additional compensation. Par agreed to entry in February 2016. Par agreed to provide backup manufacturing services and, like Watson, to promote AndroGel.

\section{B. Settlements not implicating exclusivity}

For the three drugs in this section, no generic filer had potential eligibility to the exclusivity period, either because there was no patent for the first filer to challenge, as with Ovcon 35, or because the particular procedure used for innovator approval did not allow for it, as with Biaxin $\mathrm{XL}$, or because the generic

\footnotetext{
139 See Watson Pharmaceuticals Receives FDA Approval for Testosterone Gel Product, PR Newswire, Jan. 30, 2006 (relying upon IMS Health figures).

${ }^{140}$ The agreements are with Unimed, a subsidiary of Solvay.

141 Solvay Settles Dispute with Par, Watson, Associated Press, Sept. 13, 2006; Watson and Unimed Pharmaceuticals, Inc. Settle Lawsuit Over AndroGel Testosterone Gel, Sept. 13, 2006 (notes forfeiture); Par Pharmaceutical Announces Agreement with Unimed Pharmaceuticals to Settle Androgel Patent Litigation.

142 Compare August 31, 2015 and February 26, 2016.

${ }_{143}$ Par paid generic firm Paddock $\$ 6$ million for rights to the ANDA of Paddock, another generic firm.

144 Press Release, Unimed Pharmaceuticals, Inc., Unimed Pharmaceuticals, Inc. Settles AndroGel Litigation with Watson Pharmaceuticals, Inc. and Paddock Laboratories/Par Pharmaceutical Companies, Inc. (Sept. 13, 2006) (link).
} 
firm used a procedure that does not provide for an exclusivity period, as with Alphagan.

\section{Ovcon 35}

Norethindrone and ethinyl estradiol, sold by Warner Chilcott ${ }^{145}$ under the brand name Ovcon 35, is an oral contraceptive. Worldwide sales of Ovcon 35 in 2004 , the year of settlement, were $\$ 71.5$ million. ${ }^{146}$

Warner Chilcott and Barr reached agreement in March 2004. ${ }^{147}$ Warner Chilcott agreed to pay Barr $\$ 20$ million. No exclusivity period was at issue because Ovcon 35 is not protected by a patent. The major benefit to Warner Chilcott was that Barr agreed not to enter the market until May 2009. ${ }^{148}$ Barr agreed to serve as a second supplier, in exchange for additional compensation.

The Ovcon 35 settlement has attracted several antitrust challenges. The FTC filed a complaint in 2005, leading to a settlement with Warner Chilcott and Barr's entry in 2006. Barr remained in the case, and in 2007 the district court denied Barr's motion to dismiss. ${ }^{149}$ In addition, state attorneys general have brought suit, and eight private class action suits are pending. ${ }^{150}$

\section{Alphagan}

Brimonidine tartrate $0.15 \%$ ophthalmic solution, sold by Allergan under the brand name Alphagan, is a medication to treat glaucoma by lowering

145 Warner Chilcott was previously known as Galen Holdings PLC.

${ }^{146}$ For twelve months ending September 2004. See Complaint at 8, FTC v. Warner Chilcott Holdings Co. III, Ltd., 2006 WL 3302862 (D.D.C. 2006) (No. 1:05-cv-02179-CKK) (link) (noting \$71.5 million in sales but not making explicit whether U.S. or worldwide); Warner Chilcott PLC Announces Strong Results for the Fourth Quarter Ended 30 September 2004, PR Newswire, Oct. 27, 2004 (noting total Ovcon sales, presumably including non-U.S. sales, of $\$ 71.5$ million).

147 Agreement reached in principle in September 2003. See Barr Pharmaceuticals 10-Q, supra note 2 .

148 According to the FTC complaint, the agreement was to not enter for five years. But the same document elsewhere describes a May 2009 entry date.

${ }^{149}$ FTC complaint, Dec. 2005 (link); Press Release, FTC, Consumers Win as FTC Action Results in Generic Ovcon Launch (Oct. 24, 2006) (link) (announcing generic launch after FTC settlement with Warner Chilcott); FTC v. Warner Chilcott Holdings Company III, Ltd., 2007 WL 158746 (D.D.C. Jan. 22, 2007) (denying motion to dismiss).

150 See Barr Pharmaceuticals 10-Q, supra note 2. 
intraocular pressure. U.S. sales in 2006 were around \$200 million for Alphagan and related businesses. ${ }^{151}$

Two patent suits are relevant to the subsequent settlement. ${ }^{152}$ In April 2004, Alcon filed a paper NDA with a paragraph IV certification. In August 2004, Allergan filed suit in the District of Delaware, asserting two patents against Alcon. ${ }^{153}$ Allergan also filed a second suit in California district court asserting several patents pertaining to ocular antibiotics against the Alcon product.

Allergan and Alcon reached agreement in March 2006. ${ }^{154}$ Alcon benefited from the dismissal of the second suit. As for the exclusivity period, Alcon had no entitlement to begin with because it filed a paper NDA rather than an ANDA. ${ }^{155}$ Alcon agreed to enter in September 2009 as a "co-exclusive licensee." Entry is earlier if Allergan converts customers to two other products, a $0.1 \%$ solution and Combigan, rapidly enough.

\section{Biaxin $\mathrm{XL}$}

Clarithromycin in extended release form, sold by Abbott under the brand name Biaxin XL, is an antibiotic. U.S. sales in 2006, the year of settlement, were $\$ 151$ million (for both Biaxin XL and Biaxin). ${ }^{156}$

Teva filed an ANDA seeking to market Biaxin XL upon the May 2005 expiration of the compound patent. ${ }^{157}$ Biaxin was approved under a statutory scheme, since repealed, that does not provide for a Paragraph IV certification, 30month stay, or 180-day exclusivity period. In March 2005, Abbott filed an

151 Allergan Reports Fourth Quarter Operating Results, Jan. 31, 2007 (\$295.9 million worldwide sales in 2006 for Alphagan P, Alphagan, and Combigan; \$277.2 million in 2005; overall domestic sales, across all lines of business, were $67.4 \%$ and $67.5 \%$, respectively; applying the overall domestic percentage yields $\$ 199.4$ million and $\$ 187.1$ million) (link). See also drugs.com (reporting $\$ 180$ million in U.S. sales in 2005).

152 See Allergan v. Alcon, No. 04-968, 2005 WL 3336535 (D. Del. Dec. 8, 2005); Letter from FDA to Alcon (May 22, 2006) (link) (approving drug, and noting Apr. 27, 2004 filing of paper NDA).

153 U.S. Patent No. 6,673,337 and U.S. Patent No. 6,641,834

${ }_{154}$ Alcon, Alcon and Allergan Reach Agreement on Brimonidine $0.15 \%$ Patent Litigation, Business Wire, Mar. 9, 2006.

155 FDA, Ctr. for Drug Eval. \& Res., Guidance for Industry: Listed Drugs, 30-Month Stays, and Approval of ANDAs and 505(b)(2) Applications Under Hatch-Waxman, as Amended by the Medicare Prescription Drug, Improvement, and Modernization Act of 2003, at 5 n.14 (Oct. 2004) (link).

156 See Abbott Laboratories, Annual Report (Form 10-K) (Feb. 23, 2007) (link).

157 U.S. Patent 4,331,803. 
infringement suit in Illinois district court asserting two other patents. ${ }^{158}$ (A similar suit was filed against Ranbaxy in December 2004. $)^{159}$ Trial was scheduled for March 2007.

A district court granted a preliminary injunction to Abbott, but in June 2006, the Federal Circuit vacated the injunction, concluding that Teva had raised substantial questions as to the validity of the patents. ${ }^{160}$ In June 2006, Teva began selling generic Biaxin XL, then stopped when Abbott filed an emergency motion.

Abbott reached agreements with Teva and Ranbaxy in July 2006. ${ }^{161}$ Settlement terms were not disclosed, except that Teva agreed not to enter "at this time."

158 U.S. Patent No. 6,010,718, for an extended release formulation; and U.S. Patent No. $6,551,616$, a method of reducing certain side effects by using extended release.

159 See Abbott, Annual Report (Form 10-K) (Feb. 22, 2006) (link).

160452 F.3d 1331 (Fed. Cir. 2006).

161 Teva, Abbott Settle Patent Lawsuit, Daily International Pharma Alert, Aug. 2, 2006; See Abbott Laboratories, Annual Report (Form 10-K) (Feb. 23, 2007) (link) (reporting that settlement occurred). 